\title{
Characterization and evaluation of lactic acid bacteria from indigenous raw milk for potential probiotic properties
}

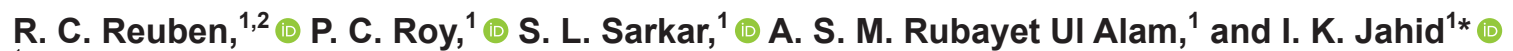 \\ ${ }^{1}$ Department of Microbiology, Faculty of Biological Science and Technology, Jashore University of Science and Technology, Jashore-7408, \\ Bangladesh \\ ${ }^{2}$ Department of Science Laboratory Technology, Nasarawa State Polytechnic, PMB 109 Lafia, Nigeria
}

\begin{abstract}
Raw milk contains wide microbial diversity, composed mainly of lactic acid bacteria (LAB), which are used as probiotics in both human and animal husbandry. We isolated, characterized, and evaluated LAB from indigenous Bangladeshi raw milk to assess probiotic potential, including antagonistic activity (against Escherichia coli O157: H7, Enterococcus faecalis, Salmonella Typhimurium, Salmonella Enteritidis, and Listeria monocytogenes), survivability in simulated gastric juice, tolerance to phenol and bile salts, adhesion to ileum epithelial cells, auto- and co-aggregation, hydrophobicity, $\alpha$-glucosidase inhibitory activity, and antibiotic susceptibility tests. The 4 most promising LAB strains showed probiotic potential and were identified as Lactobacillus casei, Lactobacillus plantarum (which produced plantaricin EF), Lactobacillus fermentum, and Lactobacillus paracasei. These strains inhibited all pathogens tested at various degrees, and competitively excluded pathogens with viable counts of 3.0 to $6.0 \log \mathrm{cfu} / \mathrm{mL}$. Bacteriocin, organic acids, and low-molecular-weight substances were mainly responsible for antimicrobial activity by the LAB strains. All 4 LAB strains were resistant to oxacillin and 3 were resistant to vancomycin and streptomycin, with multiple antibiotic resistance indices $>0.2$. After further in vivo evaluation, these LAB strains could be considered probiotic candidates with application in the food industry.
\end{abstract}

Key words: raw milk, probiotic properties, Lactobacillus, plantaricin, safety issues

\section{INTRODUCTION}

The lactic acid bacteria (LAB) are one of the most significantly important groups of bacteria in the food

Received June 11, 2019.

Accepted October 11, 2019.

*Corresponding author: ikjahid_mb@just.edu.bd industry. They have long been consumed in dairy products by people the world over and most are classified as "generally recognized as safe" (GRAS) microorganisms because they are nonpathogenic, suitable for technological and industrial processes, acid and bile tolerant, and have the ability to produce antimicrobial substances (Shehata et al., 2016). In the last decade, the LAB have received increased attention and are widely used as probiotics, live microorganisms that exert health benefits on the host when ingested in adequate amount (FAO/ WHO, 2006).

The increasing acceptance of the consumption of LAB as probiotics is due to their diverse roles in suppressing cancer (Hirayama and Rafter, 2000) and lowering serum cholesterol (Guo et al., 2010); activities against diabetes (Panwar et al., 2013), obesity (Aazmi et al., 2015), allergies (Lee et al., 2014), and inflammation (Lorea Baroja et al., 2007); reducing gastrointestinal tract (GIT) and urogenital pathogens (de Vries et al., 2006); stabilizing gut microflora (Gibson et al., 1997), increasing utilization of nutrients (Guo et al., 2010) and tolerance of lactose (Silanikove et al., 2015); improving digestion (Bokhorst et al., 2015) and stimulating the immune system (Isolauri et al., 2001), among others. Exopolysaccharides secreted by LAB strains can be used to enhance fermented milk texture and viscosity during production (Ruas-Madiedo et al., 2002). Wisselink et al. (2002) further noted the ability of certain LAB strains to produce mannitol, which has numerous health benefits.

In 2011 , an estimated $\$ 27.9$ billion was spent on the purchase of probiotics worldwide, which was projected to increase to $\$ 44.9$ billion by the end of 2018 (a compound annual growth rate of $6.8 \%$ from 2013 to 2018; TMC, 2013). The global probiotics demand is expected to further increase to $\$ 83.5$ billion by 2022 (TMC, 2017). Probiotics now have extensive applications in both human and animal husbandry, especially in the treatment and control or prevention of diseases (Anandharaj and Sivasankari, 2014). The market potential of probiotics is driving increased interest in the industrial develop- 
ment of probiotics and probiotic-supplemented foods and feeds.

At present, most bacteria used as probiotics are LAB strains belonging to the genera Lactobacillus and Enterococcus; namely, L. acidophilus, L. fermentum, L. casei, L. reuteri, L. rhamnosus, L. helveticus, L. lactis, L. crispatus, L. gasseri, L. plantarum, E. faecalis, and E. faecium (Mulaw et al., 2019). Because probiotic properties and features are strain specific (Ramos et al., 2013), more studies are needed to screen and unravel the probiotic potentials of novel LAB strains with specific beneficial health effects on both humans and animals and that are of research and industrial importance.

Generally, milk and other dairy products are considered primary food sources for LAB probiotics. Fresh or fermented cow and goat milks are consumed in different regions of the world. The presence of high counts of LAB in both cow and goat milks as beneficial microbiota indicates a source for explorations of biological materials of considerable public health importance and vast applications in the dairy industry (Khedid et al., 2009). Although researchers from other countries have screened and characterized LAB probiotic strains from various dairy products and food or animal sources, we aimed to describe the probiotic potentials of LAB strains obtained from cow and goat milk samples in Bangladesh.

\section{MATERIALS AND METHODS}

\section{Isolation and Phenotypic Characterization of LAB}

Forty samples, 20 each of fresh cow and goat milk, were randomly obtained from different locations in Jashore, Bangladesh, in sterile corked plastic tubes followed by immediate storage in a $4^{\circ} \mathrm{C}$ icebox, transportation to the laboratory, and examination for the presence of LAB upon arrival. To identify LAB, $10 \mathrm{~mL}$ of each sample was enriched in $40 \mathrm{~mL}$ of de Man, Rogosa, and Sharpe (MRS) broth (Hi-Media, Mumbai, India; (Sharifi Yazdi et al., 2017), and stirred overnight in a shaking incubator at $37^{\circ} \mathrm{C}$ (Wisd Laboratory Instruments, Seoul, South Korea) under aerobic conditions. All tubes with visible turbidity were further cultured on MRS agar plates (Hi-Media) followed by incubation for 24 to $72 \mathrm{~h}$ at $37^{\circ} \mathrm{C}$ under aerobic conditions. Then, individual colonies from each plate were selected and purified through 3 successive transfers on MRS agar. Finally, the pure isolates were characterized as LAB by Gram staining, cell morphology, catalase test, and coagulase reaction according to standard procedures (Sharpe, 1979), wherein gram-positive, catalase- and coagulase-negative isolates were selected before being stored at $-20^{\circ} \mathrm{C}$ in MRS broth plus $28 \%$ glycerol (El Soda et al., 2003).

\section{Probiotic Properties of LAB Strains}

Antagonistic Activity of the LAB Strains. The antagonistic activities of the LAB isolates against pathogens were determined by the agar well diffusion assay performed in triplicate according to Vinderola et al. (2008). The tested pathogens were Escherichia coli ATCC 10536, E. coli O157:H7 ATCC 43894, E. faecalis ATCC 51299, Salmonella Typhimurium ATCC 14028, Salmonella Enteritidis ATCC 13098, and Listeria monocytogenes ATCC 19113. The LAB isolates were cultured in MRS broth at $37^{\circ} \mathrm{C}$ overnight, and the targeted pathogens were precultured under the same conditions in brain heart infusion (BHI) broth (Liofilchem, Roseto degli Abruzzi, Italy). Approximately $10^{7} \mathrm{cfu} / \mathrm{mL}$ of each test pathogen was spread onto the surface of Mueller-Hinton agar (Biomark Lab, Maharashtra, India) plates. Wells punctured into the inoculated plates were filled with $100 \mu \mathrm{L}$ of cell-free supernatant (CFS) obtained from centrifugation of LAB cultures at $6,000 \times g$ for $10 \mathrm{~min}$ (Boeco, Hamburg, Germany) followed by incubation at $37^{\circ} \mathrm{C}$ for 24 h. The antimicrobial activity of the LAB strains was determined by development of inhibition zones in millimeters (with cut-off value $\geq 11 \mathrm{~mm}$ ) around the wells. An agar spot test was also conducted, as described by Armas et al. (2017), wherein a sample $(3 \mu \mathrm{L})$ of CFS of each LAB strain was spotted on a pathogen-inoculated plate in triplicate, left for $5 \mathrm{~min}$ to absorb, and then incubated aerobically at $37^{\circ} \mathrm{C}$ for $24 \mathrm{~h}$ (a clear inhibition zone $>1 \mathrm{~mm}$ around a spot was recorded as positive).

Simulated Gastric Juice Survivability Test. Simulated gastric juice was prepared according to Corcoran et al. (2005), with modifications, not including proteose peptone because it may serve as source of free amino acids (L-glutamate; Cotter et al., 2001). For each LAB strain, $1 \mathrm{~mL}$ of fresh culture was resuspended in an equal volume of PBS before centrifugation at $6,000 \times g$ for $10 \mathrm{~min}$ at $25^{\circ} \mathrm{C}$, and the pelleted cells were suspended in $5 \mathrm{~mL}$ of simulated gastric juice at $\mathrm{pH} 2$ (with and without lysozyme) followed by incubation at $37^{\circ} \mathrm{C}$ for 90 min with constant stirring. At different time intervals $(0,30,60$ and $90 \mathrm{~min})$, samples were taken and serially diluted in maximum-recovery diluent up to $10^{-8}$, seeded on MRS agar plates, and incubated at $37^{\circ} \mathrm{Cfor} 48 \mathrm{~h}$ (Corcoran et al., 2005).

Bile Salt and Phenol Tolerance Test. To assess bile salt tolerance, overnight LAB cultures were resuspended in sterile PBS ( $\mathrm{pH} 7.2$ ) after centrifugation at $6,000 \times g$ for $10 \mathrm{~min}$ at $25^{\circ} \mathrm{C}$, adjusted to $10^{8} \mathrm{cfu} / \mathrm{mL}$, added to fresh MRS broth containing $0.3 \%$ (wt/vol) 
bile salt (Merck KGaA, Darmstadt, Germany), and subsequently incubated for $6 \mathrm{~h}$ at $37^{\circ} \mathrm{C}$. The viability of cells was determined after 0,3 , and $6 \mathrm{~h}$ of incubation by serial dilution and plating onto MRS agar (Jose et al., 2015). The phenol tolerance of LAB strains was determined by growing the strains in MRS broth containing increasing concentrations $(0.1-0.4 \%)$ of phenol at $37^{\circ} \mathrm{C}$ for $24 \mathrm{~h}$ (Hoque et al., 2010). Strain viability was assessed by measuring the absorbance by spectrophotometer (PG Instruments, Lutterworth, UK) at 620 nm after incubation.

Adherence of LAB Strains to Chicken Ileum Epithelial Cells. We tested the LAB strains for adherence to chicken epithelial cells as previously described (Rebin, 2015). Chicken ileum was aseptically collected, washed, and divided into 4 small pieces $\left(1 \mathrm{~cm}^{2}\right)$. Each piece was incubated in a cell suspension of LAB strains $\left(10^{9} \mathrm{cfu} / \mathrm{mL}\right.$ in PBS) at $37^{\circ} \mathrm{C}$ for $90 \mathrm{~min}$. After 0,30 , 60 , and $90 \mathrm{~min}$, samples were taken and screened for adherence by serial dilution and subsequent plating on MRS agar plates. Competitive pathogen exclusion is one of the primary mechanisms used by LAB in the GIT. To assay competitive adherence with pathogen (E. coli, E. coli O157:H7, Salmonella Typhimurium and Salmonella Enteritidis), we followed the above method with a minor modification: we suspended equal volumes of individual LAB strains and each pathogen $\left(10^{9} \mathrm{cfu} / \mathrm{mL}\right.$ PBS $)$ before plating onto MacConkey agar (Hi-Media) for both E. coli and E. coli O157:H7 and Salmonella Shigella Agar (Liofilchem) for Salmonella Typhimurium and Salmonella Enteritidis, respectively, followed by incubation at $37^{\circ} \mathrm{C}$ for $24 \mathrm{~h}$ for enumeration (Neal-McKinney et al., 2012).

Aggregative Abilities of LAB Strains. Autoaggregation and co-aggregation abilities, phenotypic traits for the screening of potential probiotic strain related to the adherence capability to intestinal epithelial cells of each LAB strain, were evaluated. To determine auto-aggregation, we followed the procedure of Polak-Berecka et al. (2014), with some modifications, where exactly $5 \mathrm{~mL}$ of bacterial suspension $\left(10^{8}\right)$ was vortexed (Vision Scientific, Korea) for $10 \mathrm{~s}$, and the absorbance was measured by spectrophotometer at 600 $\mathrm{nm}$ (initial optical density, $\mathrm{OD}_{\mathrm{i}}$ ); then, the suspension was incubated for $2 \mathrm{~h}$ at $37^{\circ} \mathrm{C}$. The absorbance of the supernatant after $2 \mathrm{~h}$ of incubation was subsequently measured $\left(\mathrm{OD}_{2 \mathrm{~h}}\right)$ and the auto-aggregation percentage was calculated as $\left[1-\left(\mathrm{OD}_{2 \mathrm{~h}} / \mathrm{OD}_{\mathrm{i}}\right)\right] \times 100$.

For the co-aggregation assay, $2 \mathrm{~mL}$ of each LAB isolate and each pathogen culture were mixed, vortexed, and incubated for $2 \mathrm{~h}$ at $37^{\circ} \mathrm{C}$ (Polak-Berecka et al., 2014; Armas et al., 2017). Each control tube contained $4 \mathrm{~mL}$ of each bacterial suspension (i.e., the LAB strain and the pathogen). The absorbance of each mixed suspension was then measured at $600 \mathrm{~nm}\left(\mathrm{OD}_{\text {mix }}\right)$ and compared with those of the control tubes containing the LAB strain $\left(\mathrm{OD}_{\text {strain }}\right)$ and the specific pathogen $\left(\mathrm{OD}_{\text {pathogen }}\right)$ at $2 \mathrm{~h}$ of incubation. Co-aggregation (\%) was calculated as $\left[1-\mathrm{OD}_{\text {mix }} /\left(\mathrm{OD}_{\text {strain }}+\mathrm{OD}_{\text {pathogen }}\right) / 2\right]$ $\times 100$.

Hydrophobicity Assay. The cell surface hydrophobicity of LAB cells, as a measure to evaluate adherence to hydrocarbons, was evaluated according to the method of Abbasiliasi et al. (2017). Three tubes, each containing $3 \mathrm{~mL}$ of each LAB strain suspension in PBS $(\mathrm{pH} 7.2)$ at $10^{8} \mathrm{cfu} / \mathrm{mL}$, were mixed with the solvent $n$-hexadecane $(1 \mathrm{~mL})$ and vortexed for $1 \mathrm{~min}$. The mixture was subsequently allowed to separate into 2 phases by standing for 5 to $10 \mathrm{~min}$, after which the OD (at $600 \mathrm{~nm}$ ) of the aqueous phase was measured with a spectrophotometer. Bacterial affinity to the solvent (hydrophobicity) was expressed using the formula (1 $\left.-\mathrm{A}_{10 \min } / \mathrm{A}_{0 \text { min }}\right) \times 100$, where $\mathrm{A}_{10 \text { min }}$ and $\mathrm{A}_{0 \text { min }}$ are the absorbance at 10 and 0 min, respectively.

$\alpha$-Glucosidase Inhibitory Activity of $L A B$ Strains. We assessed the $\alpha$-glucosidase inhibitory activity of LAB strains as described by Kim et al. (2011), with slight modifications. An overnight culture of each LAB strain was centrifuged for $15 \mathrm{~min}$ at $4,000 \times g$ and resuspended in PBS $(50 \mu \mathrm{L})$. Exactly $50 \mu \mathrm{L}$ of $3 \mathrm{mM}$ $p$-nitrophenol- $\alpha$-D-glucopyranoside $(p \mathrm{NPG})$ was added and incubated at $37^{\circ} \mathrm{C}$ for $15 \mathrm{~min}$. Then, $\alpha$-glucosidase $(50 \mu \mathrm{L})$ was added and the enzymatic reaction was allowed to proceed at $37^{\circ} \mathrm{C}$ for $30 \mathrm{~min}$ and stopped by the addition of $50 \mu \mathrm{L}$ of $0.1 \mathrm{M} \mathrm{Na}_{2} \mathrm{CO}_{3}$. The release of nitrophenol was measured as absorbance at $405 \mathrm{~nm}$ using a microplate reader. The formula $(1-\mathrm{A} / \mathrm{B}) \times 100$ was used to calculate the inhibition of $\alpha$-glucosidase activity of LAB strains, where A was the absorbance of the reactants with sample and $B$ was the absorbance of the reactants without sample (negative control). Acarbose was used as the standard reference (positive control).

Characterization of $L A B$ Antimicrobial Substances. We selected LAB strains with probiotic potential and further tested for the production of antimicrobial substances, mainly bacteriocins, organic acids, and hydrogen peroxide using the agar well diffusion technique, as previously described (Prabhurajeshwar and Chandrakanth, 2017) with modifications. Overnight cultures of LAB grown in MRS broth were centrifuged at $6,000 \times g$ for $10 \mathrm{~min}$, and the supernatants were collected and divided into 4 treatments: one was heat treated (boiled) for $10 \mathrm{~min}$, the second was neutralized to $\mathrm{pH} 7$ with $6 \mathrm{~N} \mathrm{NaOH}$ (Fisher Scientific, Pittsburgh, PA), the third was treated with $0.5 \mathrm{mg} /$ $\mathrm{mL}$ catalase (Hi-Media), and the fourth was untreated. These supernatants were subsequently filter sterilized $(0.22 \mu \mathrm{m})$, and $100 \mu \mathrm{L}$ of each supernatant was placed 
into wells bored in agar plates inoculated with $1 \%$ (vol/vol) overnight cultures of indicator pathogens, as previously listed. The plates were incubated at $37^{\circ} \mathrm{C}$ overnight, and the diameters $(\mathrm{mm})$ of inhibition zones were measured.

\section{Characterization of LAB Strains and Bacteriocins}

For biochemical identification, the carbohydrate fermentation profiles of potential LAB probiotic strains were investigated using API $50 \mathrm{CH}$ strips and API CHL medium according to the manufacturer's instructions (API System, BioMérieux, Marcy-l'Étoile, France). The APIweb software version 5.0 (BioMérieux) was used in the interpretation of the results. The molecular identification of LAB strains was conducted by $16 \mathrm{~S}$ rRNA amplification, sequencing, and analysis, using universal primers (Supplemental Table S1; https:// doi.org/10.3168/jds.2019-17092). Screening for known bacteriocin genes, including those encoding pediocin, enterocin, nisin, plantaricin, lactococcin $\mathrm{A}$, and lacticin 481, was conducted using the primers listed in Supplemental Table S1. The PCR were conducted using a total volume of $20 \mu \mathrm{L}$, containing $10 \mu \mathrm{L}$ of Master Mix (GoTaq Green Master Mix, Promega, Madison, WI), $0.5 \mu \mathrm{L}$ each of forward and reverse primers, 6 $\mu \mathrm{L}$ of nuclease-free water, and $2 \mu \mathrm{L}$ of DNA template using a thermal cycler (SimpliAmp Thermal Cycler, ThermoFisher Scientific, Waltham, MA). Afterward, PCR amplicons were purified using the Wizard SV Gel and PCR Clean-Up System (Promega), and sequenced using Z-BigDye Terminator v3.1 cycle sequencing kit (Applied Biosystems, Foster City, CA). Raw data were generated using an ABI Genetic Analyzer (Applied Biosystems), before data assembly using with SeqMan version 7.0 (DNAStar Inc., Madison, WI). Sequence data were further compared with that in the National Center for Biotechnology Information (NCBI) GenBank database, using BLAST (https://www.ncbi.nlm .nih.gov/genbank/) for the final identification of the LAB strains followed by the submission of sequence.

\section{Safety Analysis of Probiotic Strains}

We assessed the hemolytic activities of LAB strains showing antagonistic activity during initial screening by the presence of $\alpha / \alpha$ (a small zone of greenish-brownish discoloration of the medium, indicating reduction of hemoglobin to methemoglobin), $\beta / \beta$ (clear, colorless or light yellow zone surrounding the colonies depicting total lysis of red blood cells), and $\gamma / \gamma$ (with no change observed in the medium) hemolysis following the protocol of Maragkoudakis et al. (2006). In the antibiotic susceptibility test, we examined promising screened and characterized LAB isolates using the agar disc diffusion method (Bauer et al., 1966). Twelve antibiotics were tested (Hi-Media): penicillin G (2 units), ceftriaxone $(30 \mu \mathrm{g})$, ampicillin $(25 \mu \mathrm{g})$, vancomycin $(30 \mu \mathrm{g})$, oxacillin $(1 \mu \mathrm{g})$, streptomycin $(10 \mu \mathrm{g})$, chloramphenicol (30 $\mu \mathrm{g})$, gentamicin $(10 \mu \mathrm{g})$, erythromycin $(10 \mu \mathrm{g})$, tetracycline $(10 \mu \mathrm{g})$, novobiocin $(30 \mu \mathrm{g})$, and ciprofloxacin $(10 \mu \mathrm{g})$. Isolates were categorized as sensitive $(\geq 21$ $\mathrm{mm})$, intermediate $(16-20 \mathrm{~mm})$, or resistant $(\leq 15 \mathrm{~mm})$ (Liasi et al., 2009). The multiple antibiotics resistance (MAR) index was determined for each probiotic strain as previously described by Ngwai et al. (2011).

\section{Statistical Analysis}

All measurements were repeated independently in triplicate, and results are expressed as mean \pm standard deviation. Statistical comparisons were made when applicable using GraphPad Prism version 5.0 for Windows (GraphPad Software, San Diego, CA). Differences were considered statistically significant at $P$ $<0.05$.

\section{RESULTS}

A total of 63 isolates from cow (34) and goat (29) milk samples showed typical morphological characteristics of LAB, being gram-positive bacilli and cocci, catalase- and coagulase-negative, and nonmotile (Sharpe, 1979). These isolates were identified and used to selecting prominent strains based on probiotic properties, molecular identification and associated bacteriocins, production of antagonistic substances, and safety.

\section{Probiotic Properties of LAB Strains}

Antagonistic Activity. Of the 63 LAB isolates examined for antagonistic activity against 6 pathogens tested, only 13 (7 and 6 from cow and goat milk samples, respectively) inhibited these pathogens at varying degrees (Table 1). Maximum zones of inhibition were exhibited against $E$. coli by LAB strains from both cow and goat milk samples ranging from moderate (16-20 $\mathrm{mm})$ to high $(>21 \mathrm{~mm})$. Cow and goat milk isolates showed low $(11-15 \mathrm{~mm})$ to moderate $(16-20 \mathrm{~mm})$ antagonistic activities against Salmonella Typhimurium and E. faecalis. Isolates $\mathrm{C} 2, \mathrm{C} 3, \mathrm{C} 4$, and $\mathrm{C} 16$ (from cow milk) and G5, G9, G10, and G12 (from goat milk) were found to have higher antagonistic activity against pathogens. The agar spot assay confirmed the inhibitory activities of the 13 selected isolates against all the pathogens tested at different degrees (Supplemental Table S2; https://doi.org/10.3168/jds.2019-17092). Although inhibition of these pathogens by the LAB iso- 
Table 1. Antagonistic activity of potential probiotic strains from cow $(\mathrm{C})$ and goat $(\mathrm{G})$ milk samples against pathogenic bacteria by agar well diffusion technique

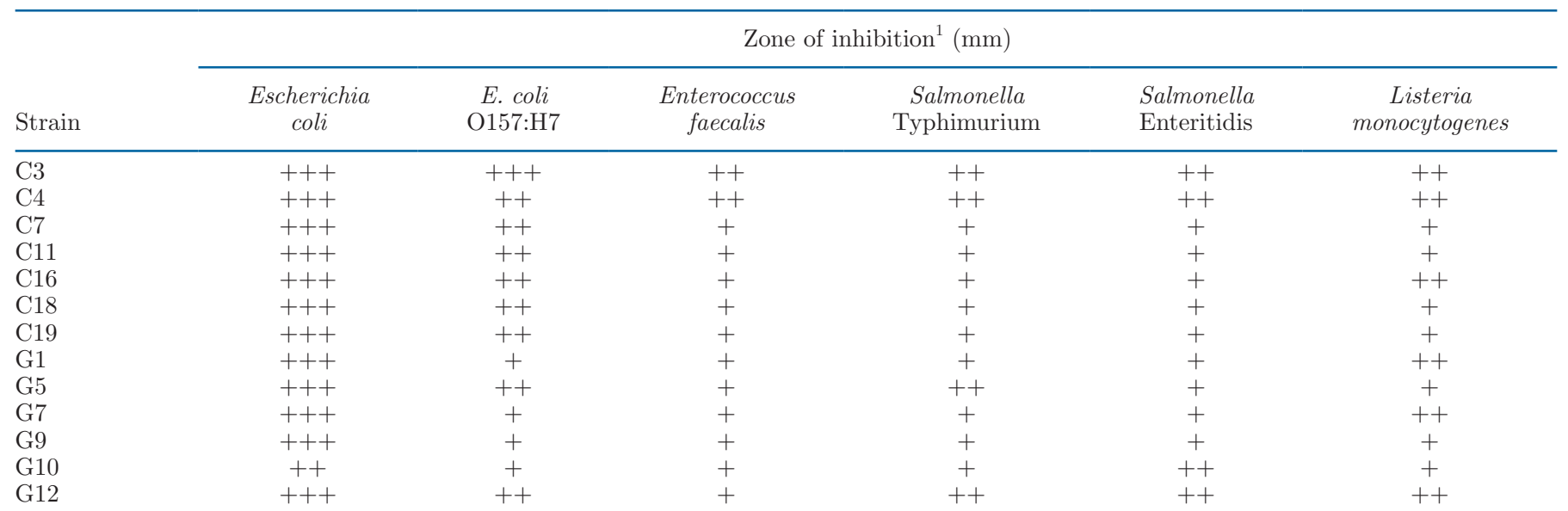

${ }^{1}$ Results of independent experiments $(\mathrm{n}=3)$ of inhibition halos, indicating low, $+(11-15 \mathrm{~mm})$, moderate, $++(15-20 \mathrm{~mm})$, and high inhibition, $+++(>21 \mathrm{~mm})$.

lates is strain specific, LAB strains $\mathrm{C} 4, \mathrm{C} 16, \mathrm{C} 18, \mathrm{G} 1$, G9, and G12 showed greater activity mainly against $E$. coli. Activity against L. monocytogenes (by LAB strains from cow milk), E. faecalis, and Salmonella Enteritidis (by LAB strains from goat milk) was the least recorded.

Survivability in Simulated Gastric Juice, Bile Salts, and Phenol. The effect of simulated gastric juice (with and without lysozyme) at $\mathrm{pH} 2.0$ on LAB isolates is presented in Figure 1. Isolates $\mathrm{C} 7$ and $\mathrm{C} 11$ failed to survive in simulated gastric juice with lysozyme at $\mathrm{pH} 2.0$ after 60 and $90 \mathrm{~min}$ of incubation, and only one isolate from goat milk (G12) was unable to survive in the same simulated environment after $90 \mathrm{~min}$ of incubation. The LAB strains C3, C4, C16, C18, C19, G1, G5, G7, G9, and G10 were selected for subsequent screenings.

The LAB strains that survived simulated gastric juice with lysozyme were also able to show bile salt tolerance at varying degrees $(P>0.05)$, with values ranging from $8.919 \pm 0.051$ to $9.162 \pm 0.193 \log _{10} \mathrm{cfu} / \mathrm{mL}$. Nevertheless, LAB strains C19 and G5 were observed to have lower microbial counts than other strains examined after $6 \mathrm{~h}$ of incubation (Table 2).

The effect of increased phenol concentration (0.1$0.4 \%$ ) on the growth of LAB isolates is shown in Figure 2. Although all isolates tolerated phenol at 0.1 and $0.2 \%$, we detected a difference $(P<0.05)$ in the viability of isolates at 0.3 and $0.4 \%$ phenol. Only 4 isolates (C3, C16, G9, and G10) were able to tolerate $0.4 \%$ phenol, so they were selected for the next examination.

Adherence Properties of $L A B$ Strains. All of the examined LAB strains adhered to epithelial cells while increasing steadily in total viable counts from 2.2 to $>4.5 \log \mathrm{cfu} / \mathrm{cm}^{3}$ from 0 to $90 \mathrm{~min}$ (Figure 3).
Additionally, we assessed the ability of LAB strains to competitively adhere to chicken ileum epithelial cells while excluding pathogens. The LAB strains from cow milk showed the highest ability to competitively exclude pathogens while adhering to ileum cells, with a difference $(P<0.001)$ in survival ranging from 5.02 \pm 0.03 to $5.25 \pm 0.10 \mathrm{log} \mathrm{cfu} / \mathrm{cm}^{3}$ and with pathogen viable counts between $2.61 \pm 0.17$ and $4.14 \pm$ $0.17 \mathrm{log} \mathrm{cfu} / \mathrm{cm}^{3}$ after $90 \mathrm{~min}$. Survival of goat milk strains ranged from $3.89 \pm 0.11$ to $3.20 \pm 14 \log \mathrm{cfu} /$ $\mathrm{cm}^{3}$ and pathogen viability was between $3.31 \pm 0.01$ and $2.75 \pm 0.08 \log \mathrm{cfu} / \mathrm{cm}^{3}$. Nevertheless, Salmonella Typhimurium slightly outgrew LAB strain G10, albeit not significantly $(P>0.05$; Figure 4$)$.

Aggregative Potential and Hydrophobicity. The results showing auto- and co-aggregation abilities of all the LAB strains examined are shown in Table 3. The auto-aggregation of the LAB strains was between 38.5 \pm 13.44 and $54.50 \pm 7.78 \%$. The highest percentage of auto-aggregation $(54.50 \pm 7.78)$ was observed in strain C3 from cow milk; strains G9 and G10 showed relatively high auto-aggregation ability but did not differ $(P$ $>0.05)$ from that of the other LAB strains examined.

For co-aggregation ability with pathogens, LAB strain C3 showed significant $(P<0.013)$ co-aggregation ability with all tested pathogens: $96.78 \pm 2.91,93.44$ $\pm 0.98,92.08 \pm 2.96,89.23 \pm 0.26,80.79 \pm 2.53$, and $78.51 \pm 0.73 \%$ for E. coli, E. faecalis, E. coli O157: H7, Salmonella Typhimurium, Salmonella Enteritidis, and L. monocytogenes, respectively. Strain C16 exhibited significant $(P<0.032)$ co-aggregation ability with all pathogens except Salmonella Enteritidis. Nevertheless, compared with cow milk, all strains from goat milk showed less co-aggregation against pathogens, with the 

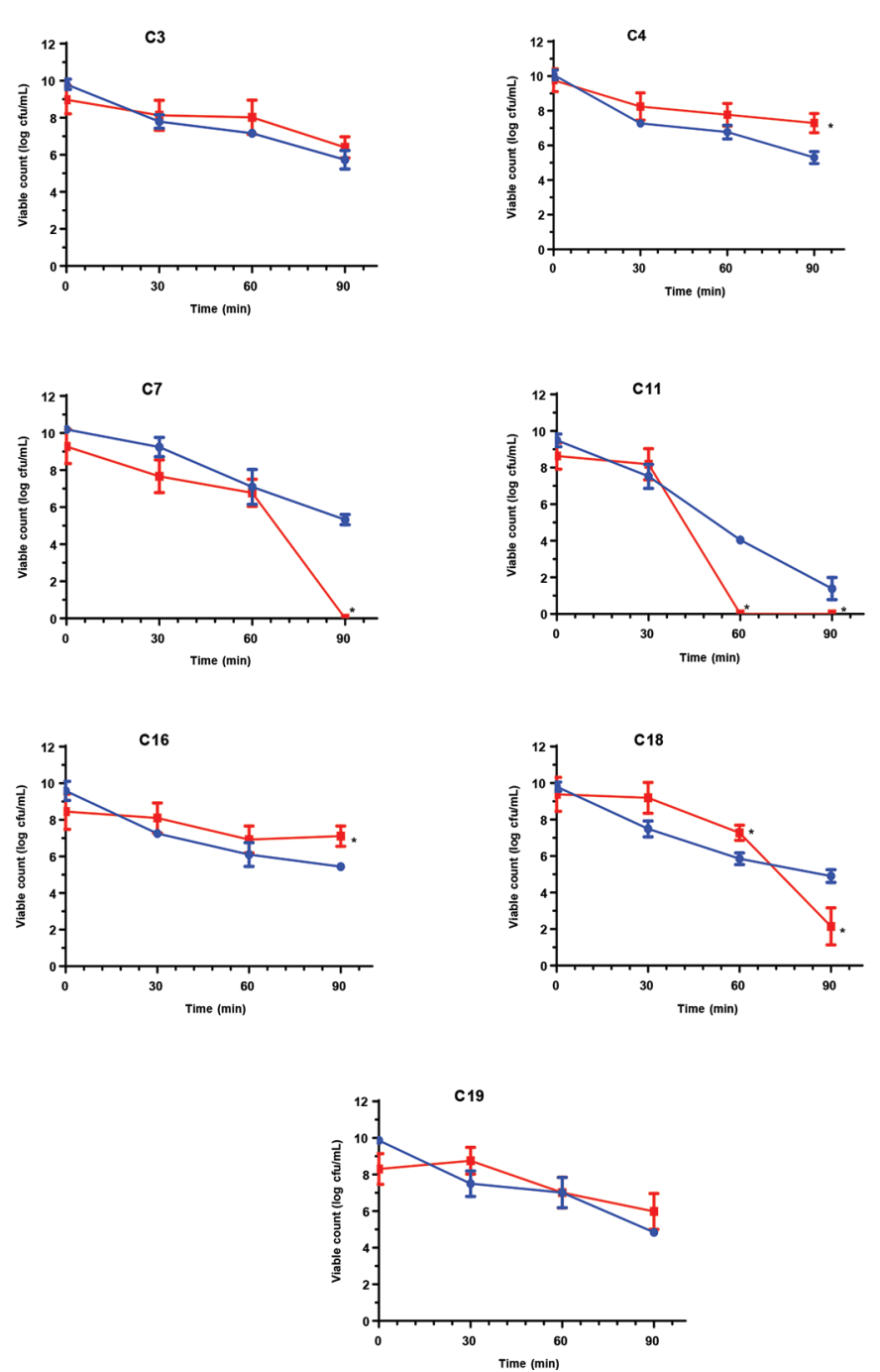

Figure 1. Survival of lactic acid bacteria strains isolated from cow (C) and goat (G) milks in simulated gastric juice with (
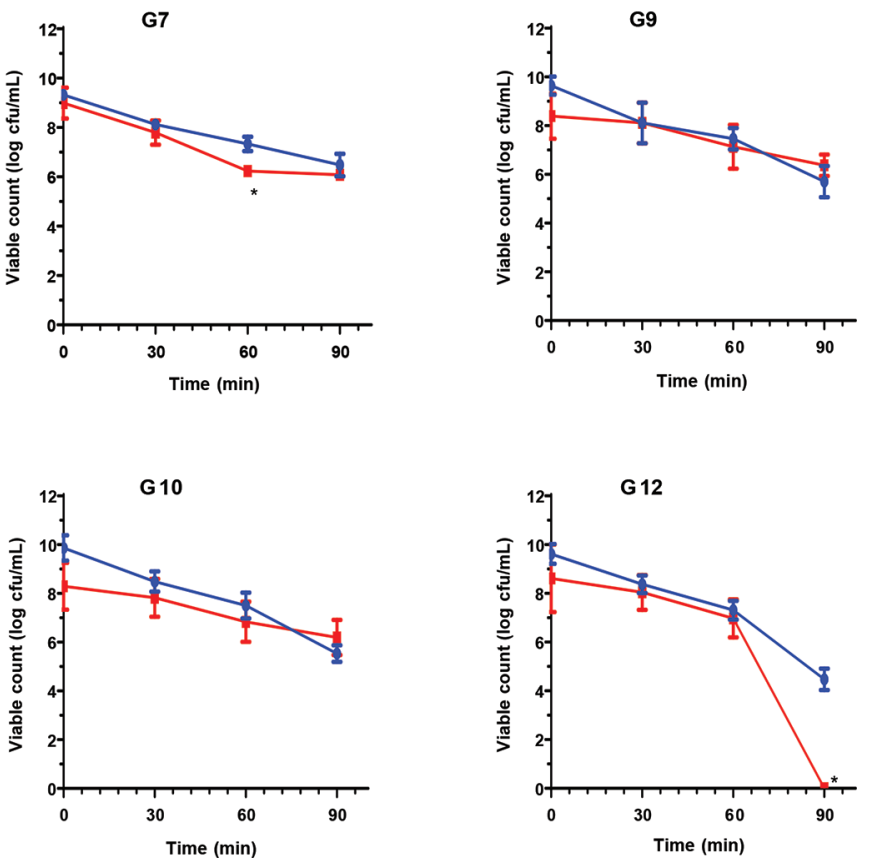
- lysozyme, pH 2.0. Data are means of triplicate experiments, and error bars indicate SD. ${ }^{*} P<0.05$ : values are significantly different.

Table 2. Viability of cow $(\mathrm{C})$ and goat $(\mathrm{G})$ milk lactic acid bacterial strains $\left(\log _{10} \mathrm{cfu} / \mathrm{mL}\right)$ after 0,3 , and $6 \mathrm{~h}$ of incubation in $0.3 \%$ bile salt $^{1}$

\begin{tabular}{lccc}
\hline & \multicolumn{3}{c}{$0.3 \%$ bile salt } \\
\cline { 2 - 4 } Strain & $0 \mathrm{~h}$ & $3 \mathrm{~h}$ & $6 \mathrm{~h}$ \\
\hline C3 & $8.96 \pm 0.06$ & $8.97 \pm 0.03$ & $8.96 \pm 0.08$ \\
C4 & $8.92 \pm 0.05$ & $8.94 \pm 0.04$ & $9.00 \pm 0.01$ \\
C16 & $9.03 \pm 0.19$ & $8.89 \pm 0.01$ & $8.90 \pm 0.01$ \\
C18 & $8.88 \pm 0.06$ & $8.87 \pm 0.07$ & $8.89 \pm 0.05$ \\
C19 & $8.88 \pm 0.01$ & $8.86 \pm 0.01$ & $8.19 \pm 0.01$ \\
G1 & $8.89 \pm 0.07$ & $8.92 \pm 0.04$ & $8.99 \pm 0.06$ \\
G5 & $8.89 \pm 0.04$ & $8.87 \pm 0.062$ & $8.02 \pm 0.00$ \\
G7 & $9.15 \pm 0.22$ & $9.06 \pm 0.09$ & $8.95 \pm 0.08$ \\
G9 & $9.02 \pm 0.17$ & $9.21 \pm 0.12$ & $9.03 \pm 0.17$ \\
G10 & $9.09 \pm 0.24$ & $9.08 \pm 0.27$ & $9.08 \pm 0.27$ \\
IV17 & & &
\end{tabular}

${ }^{1}$ Values are means \pm SD of duplicate experiments. Values did not differ significantly $(P>0.05)$. lowest co-aggregation ability ranging between $8.03 \pm$ 2.93 and $33.19 \pm 7.01 \%$ expressed by isolate G9. We observed a difference $(P<0.05)$ among all LAB isolates to the tested pathogens, except Salmonella Enteritidis and L. monocytogenes, where only C3, G9, G10, C3, C16, and G9 differed.

The cell surface hydrophobicity of the LAB strains examined is shown in Supplemental Figure S1 (https:/ /doi.org/10.3168/jds.2019-17092). Hydrophobicity was highest in isolate C3 followed by G9, C16, and G10 with 53.0, 50.50, 36.0, and $28.5 \%$, respectively. The mean values obtained did not differ $(P>0.05)$.

$\alpha$-Glucosidase Inhibitory Activity of $L A B$ Strains. The $\alpha$-glucosidase inhibitory activity of the LAB probiotic strains is shown in Supplemental Figure S2 (https://doi.org/10.3168/jds.2019-17092), with values ranging from 12.88 to $30.50 \%$. The LAB pro- 
biotic strains from goat milk had considerably higher inhibitory activities than those obtained from cow milk. We detected a difference $(P<0.05)$ between all tested strains and the positive control.

Characterization of $L A B$ Antimicrobial Substances. Table 4 shows the substances (bacteriocin, hydrogen peroxide, and organic acid) responsible for the inhibitory ability of pathogens by LAB strains. Untreated and heat treated $\left(100^{\circ} \mathrm{C}\right) \mathrm{CFS}$ of LAB strains showed wide zones of pathogen growth inhibition, indicating that substances secreted by these LAB (that are responsible for their antimicrobial activity) were not heat sensitive. Nevertheless, we detected reduced (C16) or complete loss of (C3, G9, and G10) antimicrobial activity by neutralized ( $\mathrm{pH} 7)$ CFS of LAB cultures (Table 4). These results indicated that acid production contributed greatly to the inhibitory effect of these LAB isolates and the effects of bacteriocins, as seen in some strains. Catalase-treated supernatants of LAB strains had no effect on inhibitory activities of the 4 LAB strains examined, indicating that microbial inhibitory activity by these LAB strains was not a result of hydrogen peroxide production.

\section{Molecular Characterization of LAB Strains and Bacteriocin}

Before molecular identification, we carried out biochemical identification of the LAB strains by using API 50 CHL, which identified isolates C3, C16, G9, and
G10 as L. paracasei ssp. paracasei, L. plantarum, Pediococcus pentosaceus, and $P$. pentosaceus, respectively (Supplemental Table S3; https://doi.org/10.3168/jds .2019-17092). Potential LAB strains were identified by $16 \mathrm{~S}$ rRNA amplification and sequencing. The $16 \mathrm{~S}$ rRNA sequences obtained were searched by BLAST and deposited in NCBI GenBank under accession numbers MK953801 to MK953804. Compared with the biochemical results, the $4 \mathrm{LAB}$ isolates were identified as L. casei strain C3, L. plantarum strain C16, L. fermentum strain G9, and L. paracasei strain G10 (Supplemental Table S3). Of the 4 bacteriocin genes screened using PCR, only LAB strain C16 was positive for the bacteriocin plantaricin gene (428 bp). Furthermore, we performed a BLAST search of the plantaricin sequence (GenBank accession no. MN478004) for strain C16, showing that it contained the 2-peptide bacteriocin plantaricin EF.

\section{Safety Aspects of Isolates}

To be safe for use, probiotic strains must be nonhemolytic. We ensured that the selected probiotic strains were nonhemolytic and safe for application as probiotics. The susceptibility profile of all the LAB isolates to commonly used antibiotics $(\mathrm{n}=12)$ was assessed (Supplemental Table S4; https://doi.org/10.3168/jds .2019-17092). We found that $100 \%$ of isolates showed resistance to oxacillin, $75 \%$ of isolates were resistant to vancomycin and streptomycin, and 50\% were resistant

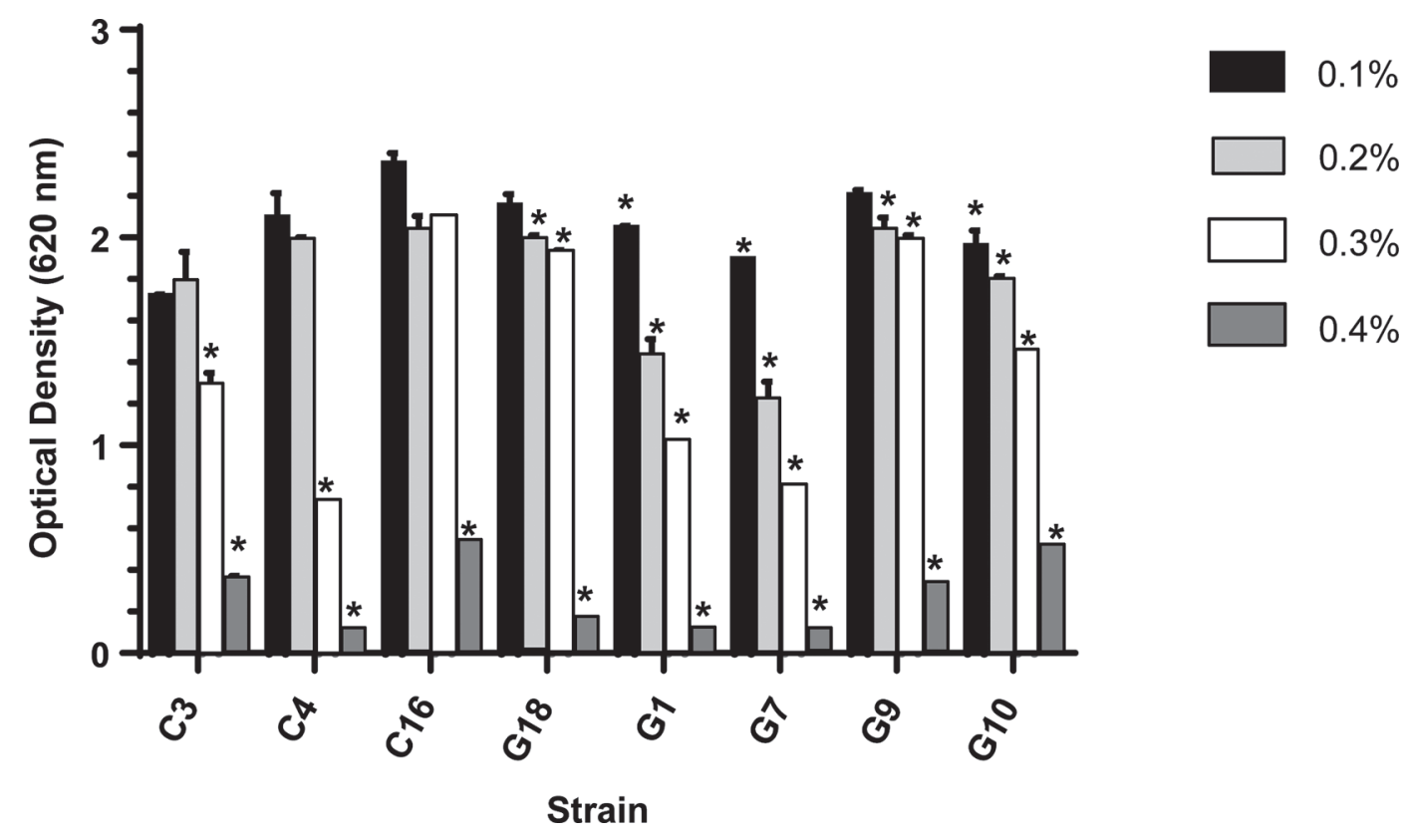

Figure 2. Tolerance to $0.10,0.20,0.30$, and $0.40 \%$ phenol by lactic acid bacteria strains from cow (C) and goat (G) milk. The data are the means of triplicate experiments, and error bars indicate $\mathrm{SD}$. ${ }^{*} P<0.05$ : values are significantly different. 


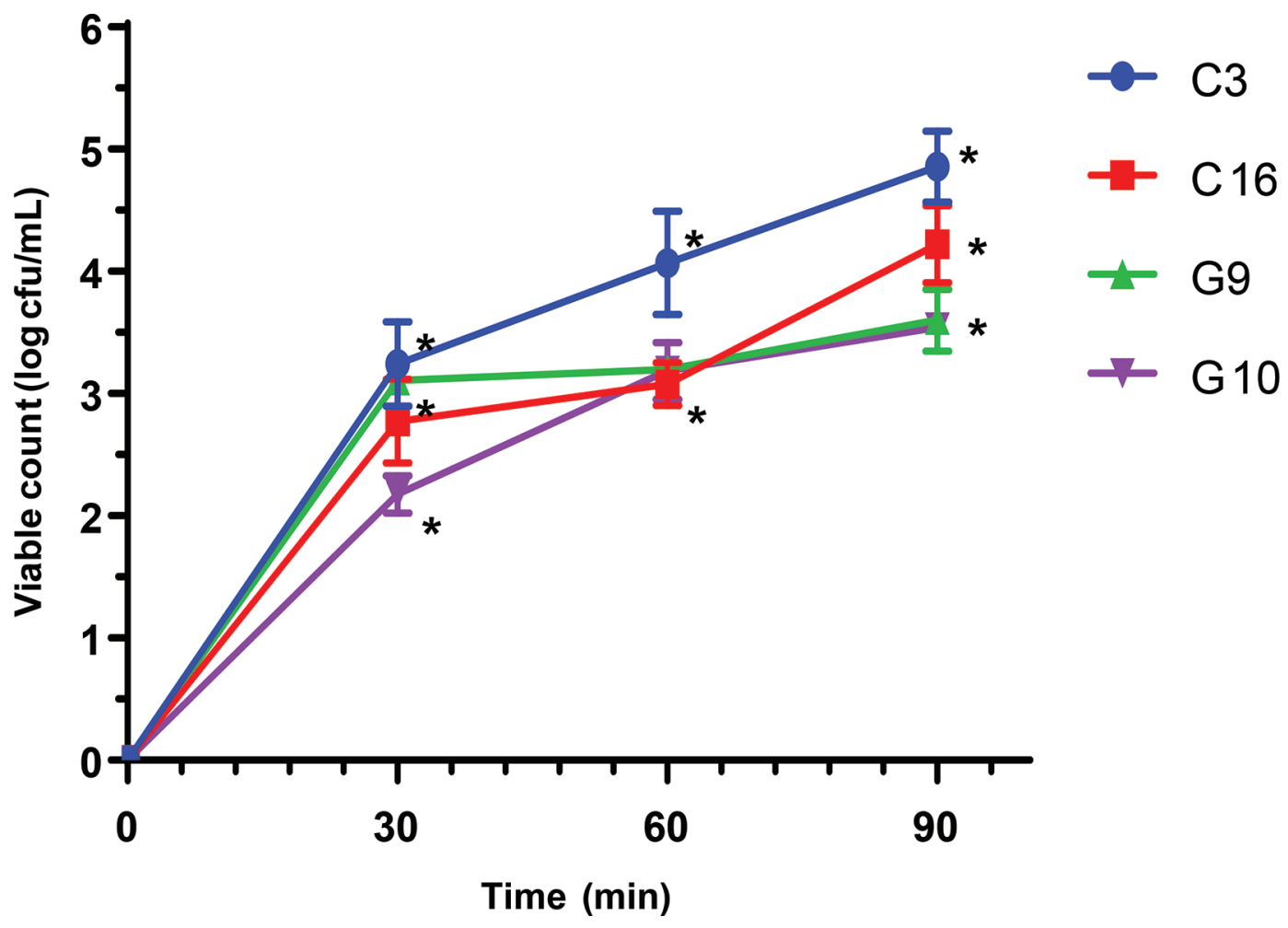

Figure 3. Adherence of lactic acid bacteria strains from cow $(\mathrm{C})$ and goat $(\mathrm{G})$ milk to poultry ileum epithelial cells. Data are the means of triplicate experiments, and error bars indicate $\mathrm{SD} .{ }^{*} P<0.05$ : values are significantly different.

to erythromycin and chloramphenicol. Furthermore, $75 \%$ of the isolates were susceptible to ampicillin and $50 \%$ were also susceptible to erythromycin, novobiocin, and tetracycline. Supplemental Table S4 shows the distribution of resistant phenotypes of antibiotic-resistant LAB strains from cow and goat milks. Four different resistant phenotypes were expressed by the isolates, with the shortest being oxacillin-vancomycin-ciprofloxacin (G9) and the longest erythromycin-oxacillin-vancomycin-chloramphenicol-streptomycin-tetracycline-oxacillin (C3). Generally, isolates from cow milk were more resistant to antibiotics than those from goat milk. The MAR indices of LAB strains showed that all were above the threshold limit (0.2). Isolates from cow milk had the highest MAR indices of 0.58 and 0.42 and isolates from goat milk had the lowest indices of 0.25 and 0.33 (Supplemental Table S5; https://doi.org/10.3168/jds .2019-17092).

\section{DISCUSSION}

Over the years, LAB from different sources, including GIT of animals as well as traditional fermented foods and dairy products, have been screened for potential probiotic properties. The LAB isolated in this study were from indigenous cow and goat milks and were characterized and evaluated for probiotic properties. A comparative evaluation of LAB from these 2 sources has not been previously reported; in-depth characterization of microbiota in Bangladesh is not often carried out. Because we wanted to characterize LAB strains only by enriching and isolating strains from raw milk samples, we used MRS medium (Sharifi Yazdi et al., 2017).

One of the crucial properties for all potential probiotic strains is their antimicrobial activity. In this study, the LAB strains showed different degrees of antagonistic activity against the tested indicator pathogens. Wider zones of inhibition were recorded against $E$. coli by LAB strains from both cow and goat milk, whereas moderate activity was recorded against Salmonella Typhimurium and E. faecalis. The broad spectrum of antagonistic activity against both gram-negative and gram-positive pathogens exhibited by the LAB strains examined here agrees with findings of other researchers (Liasi et al., 2009; Grosu-Tudor et al., 2014; Setyawardani et al., 2014; Jose et al., 2015). However, Anas et al. (2008) reported a higher degree of antagonistic activity against gram-positive pathogens than against gramnegative counterparts by strains of LAB. Nevertheless, de Almeida Junior et al. (2015) reported no relationship between the degree of LAB antagonistic activity and Gram status of pathogens tested. The agar well dif- 

$\square \mathrm{C3}$
S.Typhimurium
$\square$ E. coli
S.Enteritidis
E. coli O157: $\mathrm{H} 7$

A (Strain C3)

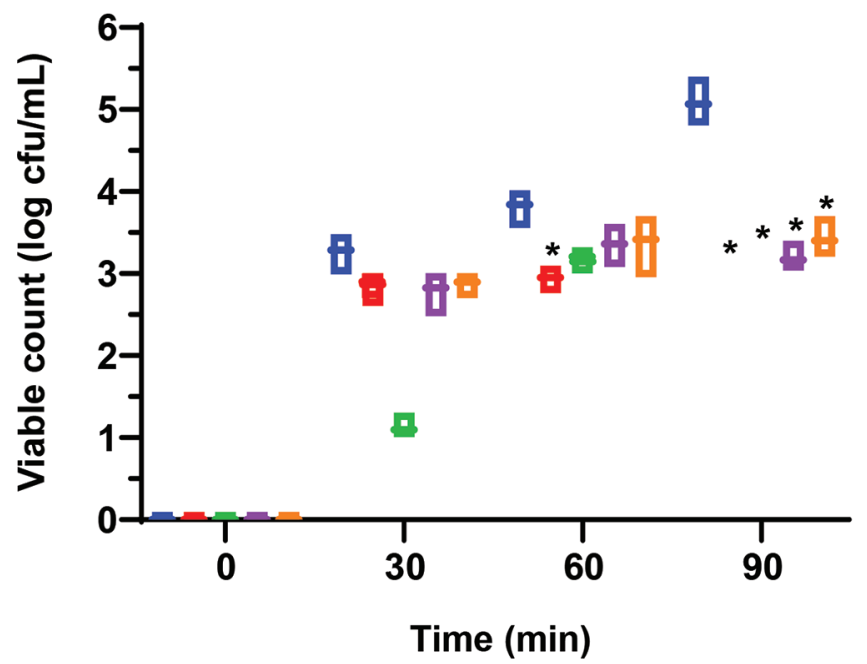

C (Strain G9)

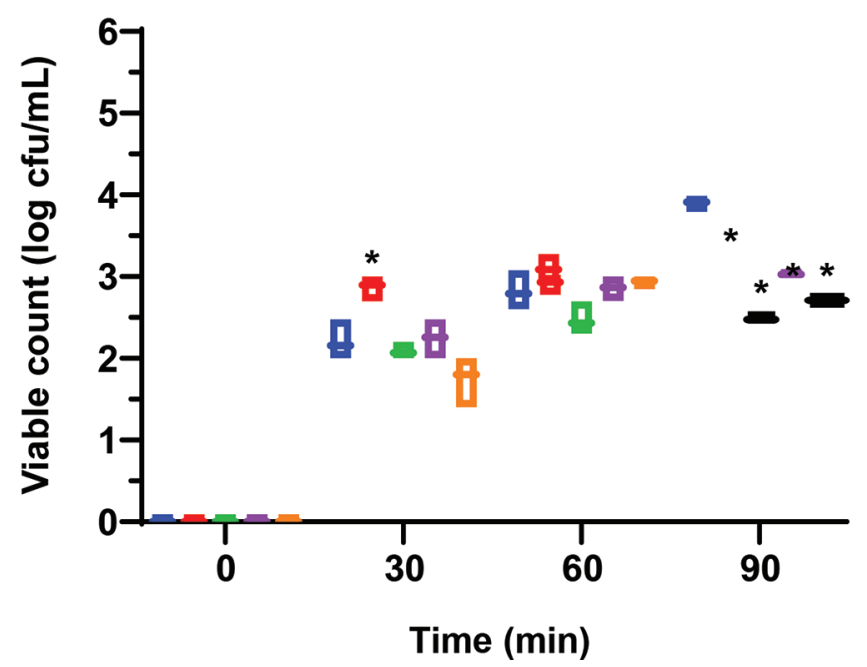

B (Strain C16)

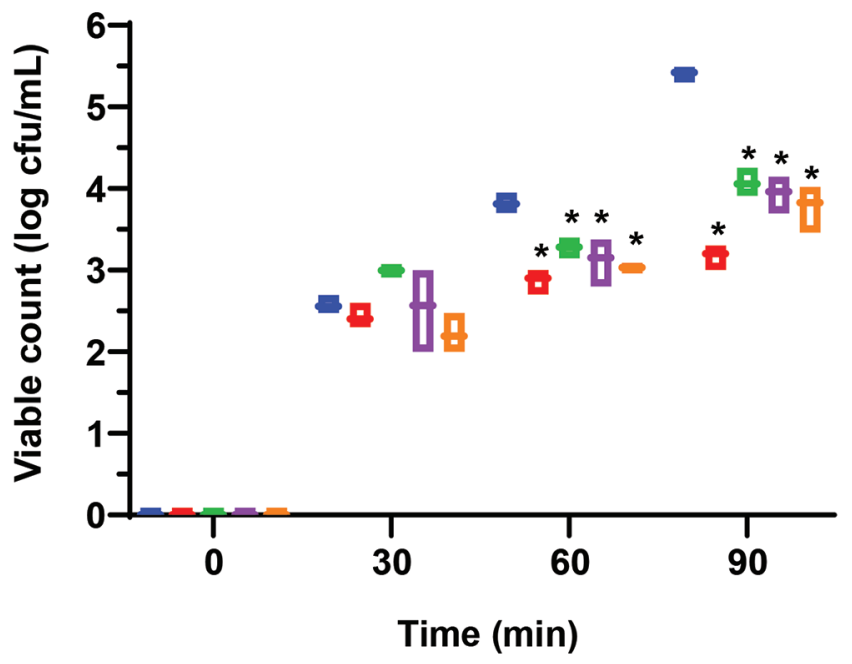

D (Strain G10)

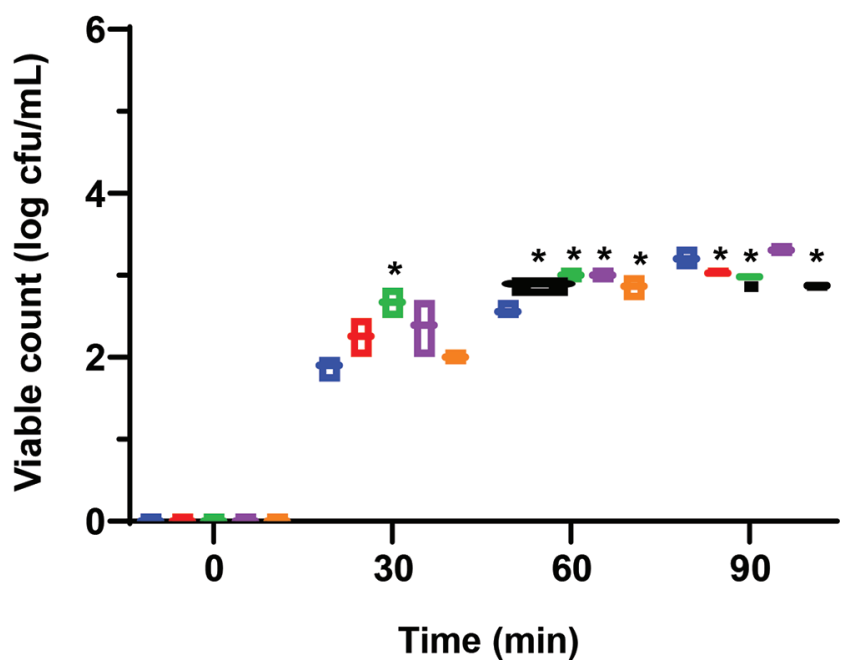

Figure 4. Competitive adherence of lactic acid bacteria strains and pathogens to poultry ileum epithelial cell. The data are the means of triplicate experiments. ${ }^{*} P<0.05$ : values are significantly different. Each box shows the viable count; midline shows the mean. E. $=$ Escherichia; S. = Salmonella .

fusion and agar spot tests used for the determination of antagonistic activity in this study gave similar results against all pathogens tested. Nevertheless, because of the specificity of the agar spot test, LAB strains that showed moderate inhibition to pathogens by agar well diffusion yielded no or weak inhibitory activity when examined by agar spot test. This finding supports that of Armas et al. (2017), who reported antimicrobial activities of LAB strain against an array of pathogens using the agar spot assay. Antimicrobial compounds including bacteriocins, organic acids (e.g., acetic, lactic, propionic, succinic acids), short-chain fatty acids, 
Table 3. Aggregation abilities of potential probiotic strains from cow $(C)$ and goat $(G) m^{1} k^{1}$

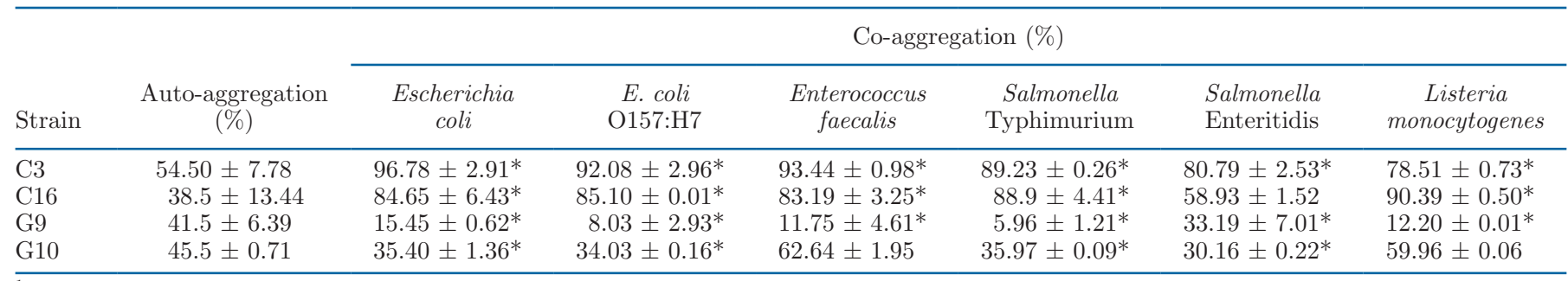

${ }^{1}$ Data are mean \pm SD from triplicate experiments.

${ }^{*} P<0.05$. Values obtained were compared against each of the LAB strains examined per each pathogen tested.

hydrogen peroxide, and other low-molecular-weight substances produced by LAB are responsible for their antimicrobial activity (Grosu-Tudor et al., 2014). Gänzle et al. (1999) previously reported that the acidic GIT microenvironment further enhances the antimicrobial potency of these compounds secreted by LAB.

In this study, $3 \mathrm{LAB}$ isolates (C11, C7, and G12) failed to survive in simulated gastric juice with lysozyme at pH 2 after 90 min of incubation. As such, they were discontinued from subsequent evaluation. The $\mathrm{pH}$ of gastric juice is approximately 3.0 and a $\mathrm{pH}$ of 2.0 is usually used in vitro to simulate an extreme GIT condition (Tsai et al., 2005). The ability of potential $\mathrm{LAB}$ probiotic strains to tolerate an acidic environment is important not only in overcoming GIT stresses, but also serves as a major requirement for their application as dietary supplements, enabling them to survive longer in acidic environments and still be effective when ingested (Prasad et al., 1998).

Probiotics are expected to pass through the GIT and survive the presence of bile salts and acidic gastric juice while exerting their beneficial effects. From this study, all the LAB strains that previously survived the simulated gastric juice environment with lysozyme were also able to survive $0.3 \%$ bile salt, with strains from goat milk showing higher viable counts after $6 \mathrm{~h}$ of incubation. These results concurred with the findings of Mathara et al. (2008), who reported that LAB strains

Table 4. Characterization of lactic acid bacteria antimicrobial substances

\begin{tabular}{|c|c|c|c|c|c|}
\hline \multirow[b]{2}{*}{ Treatment } & \multirow[b]{2}{*}{ Indicator strain } & \multicolumn{4}{|c|}{ Inhibition zone $^{1}$} \\
\hline & & C3 & C16 & G9 & G10 \\
\hline Untreated & $\begin{array}{l}\text { Escherichia coli } \\
\text { E. coli O157:H7 } \\
\text { Enterococcus faecalis } \\
\text { Salmonella Typhimurium } \\
\text { Salmonella Enteritidis } \\
\text { Listeria monocytogenes }\end{array}$ & $\begin{array}{l}+++ \\
+++ \\
+++ \\
++ \\
++ \\
++\end{array}$ & $\begin{array}{l}+++ \\
+++ \\
++ \\
++ \\
++ \\
++\end{array}$ & $\begin{array}{l}+++ \\
++ \\
++ \\
++ \\
++ \\
+\end{array}$ & $\begin{array}{l}+++ \\
+++ \\
++ \\
+ \\
++ \\
+++\end{array}$ \\
\hline Neutralized & $\begin{array}{l}\text { E. coli } \\
\text { E. coli } \mathrm{O} 157: \mathrm{H} 7 \\
\text { E. faecalis } \\
\text { Salmonella Typhimurium } \\
\text { Salmonella Enteritidis } \\
\text { L. monocytogenes }\end{array}$ & $\begin{array}{l}- \\
- \\
- \\
- \\
- \\
-\end{array}$ & $\begin{array}{l}++ \\
++ \\
+ \\
++ \\
+ \\
+\end{array}$ & $\begin{array}{l}- \\
- \\
- \\
- \\
- \\
-\end{array}$ & $\begin{array}{l}- \\
- \\
- \\
- \\
- \\
-\end{array}$ \\
\hline Heat treated & $\begin{array}{l}\text { E. coli } \\
\text { E. coli } \mathrm{O} 157: \mathrm{H} 7 \\
\text { E. faecalis } \\
\text { Salmonella Typhimurium } \\
\text { Salmonella Enteritidis } \\
\text { L. monocytogenes }\end{array}$ & $\begin{array}{l}+++ \\
+++ \\
+++ \\
++ \\
++ \\
++\end{array}$ & $\begin{array}{l}+++ \\
+++ \\
++ \\
++ \\
++ \\
++\end{array}$ & $\begin{array}{l}+++ \\
++ \\
++ \\
++ \\
++ \\
+\end{array}$ & $\begin{array}{l}+++ \\
+++ \\
++ \\
+ \\
++ \\
+++\end{array}$ \\
\hline Catalase treated & $\begin{array}{l}\text { E. coli } \\
\text { E. coli } \mathrm{O} 157: \mathrm{H} 7 \\
\text { E. faecalis } \\
\text { Salmonella Typhimurium } \\
\text { Salmonella Enteritidis } \\
\text { L. monocytogenes }\end{array}$ & $\begin{array}{l}+++ \\
+++ \\
+++ \\
++ \\
++ \\
++\end{array}$ & $\begin{array}{l}+++ \\
+++ \\
++ \\
++ \\
++ \\
++\end{array}$ & $\begin{array}{l}+++ \\
++ \\
++ \\
++ \\
++ \\
+\end{array}$ & $\begin{array}{l}+++ \\
+++ \\
++ \\
+ \\
++ \\
+++\end{array}$ \\
\hline
\end{tabular}

${ }^{1}$ Symbols show zones of inhibition:,- no inhibition; + , weak $(<14 \mathrm{~mm}) ;++, \operatorname{good}(15-19 \mathrm{~mm}) ;+++$, strong $(>20 \mathrm{~mm})$. 
from milk were tolerant to bile salts at 0.1 to $0.5 \%$. The ability of LAB from different sources to tolerate bile salt have been previously reported (Tang et al., 2018).

During digestion, phenol, a toxic metabolite with bacteriostatic properties, is secreted in the GIT (Suskovic et al., 1997). Thus, potential LAB probiotic strains must be able to withstand the effect of phenol to exert their optimal beneficial effects on their host. The selected LAB strains were able to tolerate $0.4 \%$ phenol. Shehata et al. (2016) previously observed tolerance of LAB strains to $0.4 \%$ phenol to varying degrees.

The ability of potential probiotic strains to adhere to intestinal cells is regarded as an essential criterion for probiotic selection (Collado et al., 2006). The LAB probiotic strains selected in this study were able to adhere to epithelial cells, with cell counts between 3.5 and $5.5 \mathrm{cfu} / \mathrm{cm}^{2}$ after $90 \mathrm{~min}$ of incubation. Our results agree with the findings of Collado et al. (2006) and Setyawardani et al. (2014), who reported the adhesion ability of LAB to intestinal cells. One of the beneficial effects of LAB adhesion to intestinal cells is their ability to inhibit pathogen adhesion and growth in GIT cells (Kos et al., 2003).

It is expected that potential probiotic strains can adhere to GIT cells and competitively exclude or inhibit pathogens that may cause harm to the host. All our LAB strains were able to significantly inhibit the pathogens tested at varying degrees while adhering to chicken ileum epithelial cells. Although in vitro pathogen inhibition by LAB is often reported, their ability to inhibit pathogens in vivo is very critical. Probiotics are administered orally and must be able to colonize and competitively exclude pathogens in the GIT (Neal-McKinney et al., 2012). Adhesion of LAB is a multiplex phenomenon initiating with contact with host enterocytes followed by diverse surface interactions (Kos et al., 2003). Most LAB produce cell surface proteins that, among other functions, help the bacteria bind to the epithelium of the GIT. This further enables immunoregulation by LAB, which is also relevant in the removal of pathogens (Cunningham-Rundles et al., 2000).

We further examined our potential probiotic strains for cell-binding properties; that is, autoaggregation and co-aggregation. These 2 properties must be considered when selecting potential probiotic strains. Autoaggregation (aggregation between the same microbial strains) and co-aggregation (aggregation between different microbial strains) support bacterial adhesion to epithelial cells of the host GIT and the prevention of pathogen colonization (Del Re et al., 2000). The autoaggregation of the LAB examined ranged from $41.5 \pm 6.39$ to 54.50 $\pm 7.78 \%$. All potential probiotic strains should have autoaggregation exceeding 40\% (Del Re et al., 2000).
Autoaggregation also supports biofilm formation by LAB, which further promotes colonization (Rickard et al., 2003). The LAB isolates examined in this study showed strain-specific co-aggregation ability with the pathogens tested and high co-aggregation ability was exhibited by LAB strains from cow milk. Auto- and co-aggregation abilities of LAB show discrepant results in the literature; LAB strains isolated from milk in previous studies showed low (Espeche et al., 2009) or no autoaggregation (Espeche et al., 2012). Al Kassaa et al. (2014) and Puniya et al. (2016) reported high autoaggregation (30.0 to $76.0 \%$ and 48.0 to $73.0 \%$ respectively), and $\mathrm{Xu}$ et al. (2009) reported high auto- and co-aggregation abilities of LAB strains with different foodborne pathogens.

The physicochemical characterization of LAB cell surface was conducted. Bacterial affinity to solvent ( $n$ hexadecane) was used to determine the hydrophobicity of potential LAB probiotic strains to predict their colonization abilities (Dias et al., 2013). Evaluating cell surface hydrophobicity of potential probiotic strains is a vital feature indicating the adherence potential of such strains to epithelial cells of the host GIT (Sadishkumar and Jeevaratnam, 2017). The relatively high hydrophobicity recorded showed that our LAB strains have good binding properties, and should exert sufficient barrier function in the host when ingested as probiotics.

Although $\alpha$-glucosidase inhibitory activity is strain specific, LAB strains from goat milk showed higher activity than strains from cow milk. This activity could result from a LAB's ability to produce exopolysaccharides (Ramchandran and Shah, 2009). These LAB strains could reduce the absorption of intestinal carbohydrates, thus acting as antidiabetic strains when used in humans.

When the $\mathrm{pH}$ of the supernatants from our LAB strains was adjusted to 7.0, all strains lost their antimicrobial activity against the tested pathogens except strain C16, which showed weak activity against $E$. faecalis, Salmonella Enteritidis, and L. monocytogenes, and moderate activity against E. coli, E. coli O157: H7, and Salmonella Typhimurium. These results suggest that antimicrobial inhibition by other LAB strains was mainly due to the production of acidic substances. Similarly, Tsai et al. (2004) and Todorov (2008) reported a complete loss of antagonistic activity by LAB against tested pathogens after neutralizing the supernatant. Furthermore, our study revealed that hydrogen peroxide was not responsible for antagonistic activity by the selected LAB strains. There was no effect when the supernatants of our LAB were treated with catalase. From our study, organic acids and low-molecularweight substances were mainly responsible for the antimicrobial activity by the LAB strains examined. 
Promising potential LAB probiotic strains were biochemically identified using API 50 CHL and molecularly using $16 \mathrm{~S}$ rRNA sequencing, which is more precise and accurate. Using $16 \mathrm{~S}$ universal primers, genomic DNA from LAB strains was amplified, sequenced, and identified, with a PCR product of approximately 1,500 bp. The sequences of LAB strains aligned with the $16 \mathrm{~S}$ DNA sequences obtained from GenBank. The 4 LAB isolates (C3, C16, G9, and G10, respectively) were identified as L. casei, L. plantarum, L. fermentum, and L. paracasei.

The presence of the 2-peptide bacteriocin plantaricin $\mathrm{EF}$ in strain $\mathrm{C} 16$ (L. plantarum) was consistent with the fact that the strain's antimicrobial activity may result from secretion of the bacteriocin plantaricin. Furthermore, although most bacteriocin-producing LAB strains are not antagonistic against gram-negative pathogens, our findings revealed that L. plantarum C16, which produced plantaricin, did show antagonistic activity against gram-negative pathogens. This is in agreement with findings of other researchers $\mathrm{Mu}$ hammad et al., 2019). The antimicrobial mechanism of this specific bacteriocin appears to be its ability to form pores in the cell membrane of its targets, causing efflux of small molecules, which further dissipates the transmembrane $\mathrm{pH}$ gradient $(\Delta \mathrm{pH})$ and electrical potential ( $\Delta \Psi$; Zhang et al., 2016). However, it has been reported that lactic acid secreted by LAB strains disrupts the outer membrane of gram-negative bacteria (Alakomi et al., 2000). Neutralization of the acid reduced the bacteriocinogenic activity of $L$. plantarum C16 (Table 4), although it retained antagonistic activity probably because of its anti-parallel localizing potential to both the inner and outer parts of the target cell membrane (Ekblad et al., 2016). Over the years, new bacteriocins secreted by strains of LAB have been identified and characterized, showing a wide range of antimicrobial activity against gram-positive and gramnegative pathogens (Kim et al., 2015). Although other strains were negative for the other 5 bacteriocin genes examined using PCR, they may harbor other classes of bacteriocin genes not investigated in this study or new bacteriocin genes that are yet to be identified and classified.

Out of the 4 LAB strains identified by API $50 \mathrm{CH}$ and $16 \mathrm{~S}$ rRNA sequencing, only the identification results of 2 strains: C3 (L. casei) and C16 (L. plantarum) were consistent. The other 2 strains, G9 and G10, showed inconsistencies. Sakaridis et al. (2012) and García-Hernández et al. (2016) reported similar disparities between API $50 \mathrm{CH}$ and $16 \mathrm{~S}$ rRNA sequencing. Also, the fermentation patterns of L reuteri $100-23$ was identified as $L$. fermentum ( $96.6 \%$ confidence) with the API $50 \mathrm{CH}$ identification system, whereas L. salivarius
UCC43321 was identified as L. paracasei ssp. paracasei (58.1\% confidence; Chagnaud et al., 2001). Generally, phylogenetically related LAB yield similar fermentation profiles, which further shows how inadequate biochemical methods are for accurate identification (de Vries et al., 2006). Our results confirm the accuracy of $16 \mathrm{~S}$ rRNA sequencing in the identification of LAB as suggested previously (Balcázar et al., 2007).

Susceptibility to an array of commonly used human and veterinary antibiotics should be assessed for all potential probiotic strains. This procedure is essential in detecting potential probiotic strains with transferable antibiotic resistance genes, which may be detrimental to the host. The LAB strains examined showed varying degree of resistance toward some antibiotic; strains from cow milk were resistant to ceftriaxone, ampicillin, erythromycin, oxacillin, vancomycin, chloramphenicol, streptomycin, tetracycline, and gentamicin, whereas strains from goat milk were resistant to erythromycin, oxacillin, vancomycin, ciprofloxacin, and streptomycin. Instances of antibiotic resistance were low in LAB strains from goat milk compared with those from cow milk. In literature, strains of lactobacilli are generally resistant to $\beta$-lactam antibiotics (including ceftriaxone, ampicillin, oxacillin) as a result of the presence of $\beta$-lactamase in such strains (Hoque et al., 2010; Jose et al., 2015). Similarly, aminoglycoside (gentamycin and streptomycin) and glycopeptide (vancomycin) resistance have been reported in LAB, which is associated (in most cases) with their innate resistance resulting from the impermeability of their membrane, presumably through a resistance efflux mechanism (Liasi et al., 2009). In addition, the cytochrome-mediated electron transport responsible for the uptake of drugs is absent in most LAB (Monteagudo-Mera et al., 2012). Natural resistance to ciprofloxacin as obtained in our work has also been reported by Tang et al. (2018). Some strains of LAB contain genes that are resistant to chloramphenicol (Sharma et al., 2014; Choi et al., 2018). In agreement with the reports of Sharma et al. and Choi et al., we also observed resistance to chloramphenicol by some strains of LAB. In addition, resistance to tetracycline was consistent with findings of Kim et al. (2015), congruent with most commercial probiotics (Sharma et al., 2014).

Source and geographical location of LAB are also factors that determine antibiotic susceptibility patterns of potential probiotic strains (Al Kassaa et al., 2014; Anandharaj and Sivasankari, 2014). The strain-specific molecular basis of intrinsic antibiotic resistance by most LAB strains requires further in-depth study. The intrinsic resistance of probiotic strains promotes both therapeutic and preventive benefits when administered together with antibiotics, as intestinal microbiota 
recovery becomes facilitated (Jose et al., 2015). The MAR indices recorded for LAB strains from cow milk show that these strains were obtained from an environment where there is misuse of antibiotics. Furtula et al. (2013) reported that a MAR index $>0.2$ indicates strains from an environment with free access to and abuse of antimicrobial agents. This is the case within the study area, where livestock keepers use antibiotics on their animals without restriction.

Regarding the safety of potential probiotic strains, it is expected that microbial probiotic strains should be unable to lyse red blood cells when ingested by humans or animals. Like most LAB strains (Santini et al., 2010), the 4 selected probiotic strains were all nonhemolytic and thus are safe for use.

\section{CONCLUSIONS}

In this study, 63 LAB strains were isolated from indigenous cow and goat milks in Bangladesh; only 4 of the strains met requirements for probiotics, as evaluated by broad-spectrum antagonistic activity against pathogens, competitive exclusion of pathogens, survivability in simulated gastric juice with lysozyme ( $\mathrm{pH} 2)$, and good cell surface properties. Out of the 4 strains identified by $16 \mathrm{~S}$ rRNA sequencing ( L. casei C3, L. plantarum C16, L. fermentum G9 and L. paracasei G10), only L. plantarum C16 harbored bacteriocin, which was sequenced to be a 2-peptide plantaricin EF. The suitable properties exhibited by these LAB strains make them ideal potential probiotics, especially the plantaricin-producing strain, which could be used in vivo or in combination with other strains in a multispecies probiotic for greater effectiveness.

\section{ACKNOWLEDGMENTS}

This work was financed by the Bangladesh Academy of Science (Department of Microbiology, Jashore University of Science and Technology, Jashore, Bangladesh) under BAS-USDA program code no. LSC 33.

\section{REFERENCES}

Aazmi, S., L. K. Teh, K. Ramasamy, T. Rahman, and M. Z. Salleh. 2015. Comparison of the anti-obesity and hypocholesterolaemic effects of single Lactobacillus casei strain Shirota and probiotic cocktail. Int. J. Food Sci. Technol. 50:1589-1597. https://doi.org/ 10.1111/ijfs. 12810 .

Abbasiliasi, S., J. S. Tan, F. Bashokouh, T. A. T. Ibrahim, S. Mustafa, F. Vakhshiteh, S. Sivasamboo, and A. B. Ariff. 2017. In vitro assessment of Pediococcus acidilactici Kp10 for its potential use in the food industry. BMC Microbiol. 17:121. https://doi.org/10 $.1186 / \mathrm{s} 12866-017-1000-\mathrm{z}$

Al Kassaa, I., M. Hamze, D. Hober, N.-E. Chihib, and D. Drider.2014. Identification of vaginal lactobacilli with potential probiotic properties isolated from women in north Lebanon. Microb. Ecol. 67:722-734. https://doi.org/10.1007/s00248-014-0384-7.

Alakomi, H. L., E. Skyttä, M. Saarela, T. Mattila-Sandholm, K. Latva-Kala, and I. M. Helander. 2000. Lactic acid permeabilizes gram-negative bacteria by disrupting the outer membrane. Appl. Environ. Microbiol. 66:2001-2005. https://doi.org/10.1128/AEM 66.5.2001-2005.2000.

Anandharaj, M., and B. Sivasankari. 2014. Isolation of potential probiotic Lactobacillus oris HMI68 from mother's milk with cholesterolreducing property. J. Biosci. Bioeng. 118:153-159. https://doi.org/ 10.1016/j.jbiosc.2014.01.015.

Anas, M., H. J. Eddine, and K. Mebrouk. 2008. Antimicrobial activity of Lactobacillus species isolated from Algerian raw goat's milk against Staphylococcus aureus. World J. Dairy Food Sci. 3:39-49.

Armas, F., C. Camperio, and C. Marianelli. 2017. In vitro assessment of the probiotic potential of Lactococcus lactis LMG 7930 against ruminant mastitis-causing pathogens. PLoS One 12:e0169543. https://doi.org/10.1371/journal.pone.0169543.

Balcázar, J. L., I. de Blas, I. Ruiz-Zarzuela, D. Vendrell, O. Gironés, and J. L. Muzquiz. 2007. Sequencing of variable regions of the 16S rRNA gene for identification of lactic acid bacteria isolated from the intestinal microbiota of healthy salmonids. Comp. Immunol. Microbiol. Infect. Dis. 30:111-118. https://doi.org/10.1016/j.cimid .2006.12.001.

Bauer, A. J., W. Kirby, and M. Turck. 1966. Antibiotic susceptibility testing by standardized single disc method. Am. J. Clin. Pathol. 45(4_ts):493-496. https://doi.org/10.1093/ajcp/45.4_ts.493.

Bokhorst, V. V., H. Van, P. A. Bron, and M. Kleerebezem. 2015. Improving the digestive tract robustness of probiotic lactobacilli. Pages 195-204 in Probiotics and Prebiotics: Current Research and Future Trends. Caister Academic Press, Norfolk, UK.

Chagnaud, P., K. Machinis, L. A. Coutte, A. Marecat, and A. Mercenier. 2001. Rapid PCR-based procedure to identify lactic acid bacteria: Application to six common Lactobacillus species. J. Microbiol. Methods 44:139-148. https://doi.org/10.1016/S0167 $-7012(00) 00244-X$.

Choi, A. R., J. K. Patra, W. J. Kim, and S. S. Kang. 2018. Antagonistic activities and probiotic potential of lactic acid bacteria derived from a plant-based fermented food. Front. Microbiol. 9:1963. https://doi.org/10.3389/fmicb.2018.01963.

Collado, M. C., L. Jalonen, and J. Meriluoto. 2006. Protection mechanism of probiotic combination against human pathogens: In vitro adhesion to human intestinal mucus. Asia Pac. J. Clin. Nutr. 15:570-575.

Corcoran, B. M., C. Stanton, G. F. Fitzgerald, and R. P. Ross. 2005. Survival of probiotic lactobacilli in acidic environments is enhanced in the presence of metabolizable sugars. Appl. Environ. Microbiol. 71:3060-3067. https://doi.org/10.1128/AEM.71.6.3060-3067.2005.

Cotter, P. D., C. G. Gahan, and C. Hill. 2001. A glutamate decarboxylase system protects Listeria monocytogenes in gastric fluid. Mol. Microbiol. 40:465-475. https://doi.org/10.1046/j.1365-2958 2001.02398.x.

Cunningham-Rundles, S., S. Ahrne, S. Bengmark, R. Johannliang, F. Marshall, L. Metakis, C. Califano, A. M. Dunn, C. Grassey, G. Hinds, and J. Cervia. 2000. Probiotics and immune response. Am. J. Gastroenterol. 95:S22

de Almeida Júnior, W. L. G., Í. S. Ferrari, J. V. de Souza, C. D. A. da Silva, M. M. da Costa, and F. S. Dias. 2015. Characterization and evaluation of lactic acid bacteria isolated from goat milk. Food Control 53:96-103. https://doi.org/10.1016/j.foodcont.2015 .01 .013 .

de Vries, M. C., E. E. Vaughan, M. Kleerebezem, and W. M. de Vos. 2006. Lactobacillus plantarum - Survival, functional and potential probiotic properties in the human intestinal tract. Int. Dairy J. 16:1018-1028. https://doi.org/10.1016/j.idairyj.2005.09.003.

Del Re, B., B. Sgorbati, M. Miglioli, and D. Palenzona. 2000. Adhesion, autoaggregation and hydrophobicity of 13 strains of Bifidobacterium longum. Lett. Appl. Microbiol. 31:438-442. https://doi .org/10.1046/j.1365-2672.2000.00845.x. 
Dias, F. S., F. Duarte, and F. Schwan. 2013. Evaluation of adhesive properties of presumptive probiotic Lactobacillus plantarum strains. Biosci. J. 29:1678-1686.

Ekblad, B., P. K. Kyriakou, C. Oppegård, J. Nissen-Meyer, Y. N. Kaznessis, and P. E. Kristiansen. 2016. Structure-function analysis of the two-peptide bacteriocin plantaricin EF. Biochemistry 55:5106-5116. https://doi.org/10.1021/acs.biochem.6b00588.

El Soda, M., N. Ahmed, N. Omran, G. Osman, and A. Morsi. 2003. Isolation, identification and selection of lactic acid bacterial cultures for cheese making. Emir. J. Food Agric. 15:51-71. https:// doi.org/10.9755/ejfa.v15i2.5006.

Espeche, M. C., M. C. Otero, F. Sesma, and M. E. Nader-Macias. 2009. Screening of surface properties and antagonistic substances production by lactic acid bacteria isolated from the mammary gland of healthy and mastitic cows. Vet. Microbiol. 135:346-357. https://doi.org/10.1016/j.vetmic.2008.09.078.

Espeche, M. C., M. Pellegrino, I. Frola, A. Larriestra, C. Bogni, and M. E. F. Nader-Macías. 2012. Lactic acid bacteria from raw milk as potentially beneficial strains to prevent bovine mastitis. Anaerobe 18:103-109. https://doi.org/10.1016/j.anaerobe.2012.01.002.

FAO/WHO. 2006. Probiotics in food, health and nutritional properties and guidelines for evaluation. FAO Food and Nutritional Paper. No. 85. WHO/FAO, Rome, Italy.

Furtula, V., C. R. Jackson, E. G. Farrell, J. B. Barrett, L. M. Hiott, and P. A. Chambers. 2013. Antimicrobial resistance in Enterococcus spp. isolated from environmental samples in an area of intensive poultry production. Int. J. Environ. Res. Public Health 10:1020-1036. https://doi.org/10.3390/ijerph10031020.

Gänzle, M. G., W. Sigrid, and W. P. Hammes. 1999. Effect of ecological factors on the inhibitory spectrum and activity of bacteriocins. Int. J. Food Microbiol. 46:207-217. https://doi.org/10.1016/s0168 $-1605(98) 00205-0$.

García-Hernández, Y., T. Pérez-Sánchez, R. Boucourt, J. L. Balcázar, J. R. Nicoli, J. Moreira-Silva, Z. Rodríguez, H. Fuertes, O. Nuñez, N. Albelo, and N. Halaihel. 2016. Isolation, characterization and evaluation of probiotic lactic acid bacteria for potential use in animal production. Res. Vet. Sci. 108:125-132. https://doi.org/10 .1016/j.rvsc.2016.08.009

Gibson, G. R., J. M. Saveedra, S. MacFarlane, and G. T. MacFarlane. 1997. Probiotics and intestinal infections. Pages 10-39 in Probiotic. 2: Applications and Practical Aspects. R. Fuller, ed. Chapman \& Hall, New York, NY.

Grosu-Tudor, S. S., M. M. Stancu, D. Pelinescu, and M. Zamfir. 2014 Characterization of some bacteriocins produced by lactic acid bacteria isolated from fermented foods. World J. Microbiol. Biotechnol. 30:2459-2469. https://doi.org/10.1007/s11274-014-1671-7.

Guo, X. H., J. M. Kim, H. M. Namb, S. Y. Park, and J. M. Kim. 2010. Screening lactic acid bacteria from swine origins for multistrain probiotics based on in vitro functional properties. Anaerobe $16: 321-326$.

Hirayama, K., and J. Rafter. 2000. The role of probiotic bacteria in cancer prevention. Microbes Infect. 2:681-686. https://doi.org/10 .1016/S1286-4579(00)00357-9.

Hoque, M. Z., F. Akter, K. M. Hossain, M. S. M. Rahman, M. M. Billah, and K. M. D. Islam. 2010. Isolation, identification and analysis of probiotic properties of Lactobacillus spp. from selective regional yoghurts. World J. Dairy Food Sci. 5:39-46.

Isolauri, E., Y. Sütas, P. Kankaanpää, H. Arvilommi, and S. Salminen. 2001. Probiotics: Effects of immunity. Am. J. Clin. Nutr. 73:444S450S. https://doi.org/10.1093/ajcn/73.2.444s.

Jose, N. M., C. R. Bunt, and A. M. Hussain. 2015. Comparison of microbiological and probiotic characteristics of lactobacilli isolates from dairy food products and animal rumen contents. Microorganisms 3:198-212. https://doi.org/10.3390/microorganisms3020198.

Khedid, K., M. Faid, A. Mokhtari, A. Soulaymani, and A. Zinedine. 2009. Characterization of lactic acid bacteria isolated from the one humped camel milk produced in Morocco. Microbiol. Res. 164:8191. https://doi.org/10.1016/j.micres.2006.10.008.

Kim, J. S., T. K. Hyun, and M. J. Kim. 2011. The inhibitory effects of ethanol extracts from sorghum, foxtail millet and proso millet on $\alpha$-glucosidase and $\alpha$-amylase activities. Food Chem. 124:16471651. https://doi.org/10.1016/j.foodchem.2010.08.020.

Kim, J. Y., J. A. Young, N. W. Gunther IV, and J.-L. Lee. 2015. Inhibition of Salmonella by bacteriocin-producing lactic acid bacteria derived from U.S. kimchi and broiler chicken. J. Food Saf. 35:1-12. https://doi.org/10.1111/jfs.12141.

Kos, B., J. Šušković, S. Vuković, M. Šimpraga, J. Frece, and S. Matošić. 2003. Adhesion and aggregation ability of probiotic strain Lactobacillus acidophilus M92. J. Appl. Microbiol. 94:981-987. https://doi .org/10.1046/j.1365-2672.2003.01915.x.

Lee, N. K., S. Y. Kim, K. J. Han, S. J. Eom, and H. D. Paik. 2014 Probiotic potential of Lactobacillus strains with anti-allergic effects from kimchi for yogurt starters. Lebensm. Wiss. Technol. 58:130-134. https://doi.org/10.1016/j.lwt.2014.02.028.

Liasi, S. A., T. I. Azmi, M. D. Hassan, M. Shuhaimi, M. Rosfarizan, and A. B. Ariff. 2009. Antimicrobial activity and antibiotic sensitivity of three isolates of lactic acid bacteria from fermented fish product, Budu. Malays. J. Microbiol. 5:33-37.

Lorea Baroja, M., P. V. Kirjavainen, S. Hekmat, and G. Reid. 2007. Anti-inflammatory effects of probiotic yogurt in inflammatory bowel disease patients. Clin. Exp. Immunol. 149:470-479. https:// doi.org/10.1111/j.1365-2249.2007.03434.x.

Maragkoudakis, P. A., G. Zoumpopoulou, C. Miaris, G. Kalantzopoulos, B. Pot, and E. Tsakalidou. 2006. Probiotic potentials of Lactobacillus strains isolated from dairy products. Int. Dairy J. 16:189-199. https://doi.org/10.1016/j.idairyj.2005.02.009.

Mathara, J. M., U. Schillinger, P. M. Kutima, S. K. Mbugua, C. Guigas, C. Franz, and W. H. Holzapfel. 2008. Functional properties of Lactobacillus plantarum strains isolated from Maasai traditional fermented milk products in Kenya. Curr. Microbiol. 56:315-321. https://doi.org/10.1007/s00284-007-9084-6.

Monteagudo-Mera, A., L. Rodríguez-Aparicio, J. Rúa, H. MartínezBlanco, N. Navasa, M. R. García-Armesto, and M. A. Ferrero. 2012. In vitro evaluation of physiological probiotic properties of different lactic acid bacteria strains of dairy and human origin. J. Funct. Foods 4:531-541. https://doi.org/10.1016/j.jff.2012.02.014.

Muhammad, Z., R. Ramzan, A. Abdelazez, A. Amjad, M. Afzaal, S. Zhang, and S. Pan. 2019. Assessment of the antimicrobial potentiality and functionality of Lactobacillus plantarum strains isolated from the conventional Inner Mongolian fermented cheese against foodborne pathogens. Pathogens 8:71. https://doi.org/10.3390/ pathogens8020071.

Mulaw, G., T. Sisay Tessema, D. Muleta, and A. Tesfaye. 2019. In vitro evaluation of probiotic properties of lactic acid bacteria isolated from some traditionally fermented Ethiopian food products. Int. J. Microbiol. 2019:7179514-11. https://doi.org/10.1155/2019/ 7179514

Neal-McKinney, J. M., X. Lu, T. Duong, C. L. Larson, D. R. Call, D. H. Shah, and M. E. Konkel. 2012. Production of organic acids by probiotic lactobacilli can be used to reduce pathogen load in poultry. PLoS One 7:e43928. https://doi.org/10.1371/journal .pone.0043928.

Ngwai, Y. B., H. N. Nwankwo, and M. P. Adoga. 2011. Multidrug resistant Escherichia coli from human immunodeficiency virus/acquired immunodeficiency syndrome (HIV/AIDS) patients in Keffi, Nigeria. Int. Res. J. Microbiol. 2:122-125.

Panwar, H., H. M. Rashmi, V. K. Batish, and S. Grover. 2013. Probiotics as potential biotherapeutics in the management of type 2 diabetes-Prospects and perspectives. Diabetes Metab. Res. Rev. 29:103-112. https://doi.org/10.1002/dmrr.2376.

Polak-Berecka, M., A. Waśko, R. Paduch, T. Skrzypek, and A. SrokaBartnicka. 2014. The effect of cell surface components on adhesion ability of Lactobacillus rhamnosus. Antonie van Leeuwenhoek 106:751-762. https://doi.org/10.1007/s10482-014-0245-x.

Prabhurajeshwar, C., and R. K. Chandrakanth. 2017. Probiotic potential of lactobacilli with antagonistic activity against pathogenic strains: An in vitro validation for the production of inhibitory substances. Biomed. J. 40:270-283. https://doi.org/10.1016/j.bj 2017.06.008.

Prasad, J., H. Gill, J. Smart, and P. K. Gopal. 1998. Selection and characterization of Lactobacillus and Bifidobacterium strains for 
use as probiotics. Int. Dairy J. 8:993-1002. https://doi.org/10 1016/S0958-6946(99)00024-2.

Puniya, M., K. M. Ravinder, H. Panwar, and N. Kumar. 2016. Screening of lactic acid bacteria of different origin for their probiotic potential. J. Food Process. Technol. 7:545. https://doi.org/10.4172/ 2157-7110.1000545.

Ramchandran, L., and N. Shah. 2009. Effect of exopolysaccharides and inulin on the proteolytic, angiotensin-I-converting enzymeand $\alpha$-glucosidase inhibitory activities as well as on textural and rheological properties of low-fat yogurt during refrigerated storage. Dairy Sci. Technol. 89:583-600. https://doi.org/10.1051/dst/ 2009039

Ramos, C. L., L. Thorsen, R. F. Schwan, and L. Jespersen. 2013. Strain-specific probiotics properties of Lactobacillus fermentum, Lactobacillus plantarum and Lactobacillus brevis isolates from Brazilian food products. Food Microbiol. 36:22-29. https://doi.org/10 .1016/j.fm.2013.03.010

Rebin, A. M. A. 2015. The effects of probiotics, prebiotics and synbiotics on gut flora, immune function and blood characteristics of broilers. PhD Thesis. School of Biological Sciences, University of Plymouth. UK.

Rickard, A. H., P. Gilbert, N. J. High, P. E. Kolenbrander, and P. S. Handley. 2003. Bacterial coaggregation: An integral process in the development of multi-species biofilms. Trends Microbiol. 11:94100. https://doi.org/10.1016/s0966-842x(02)00034-3.

Ruas-Madiedo, P., R. Tuinier, M. Kanning, and P. Zoon. 2002. Role of exopolysaccharides produced by Lactococcus lactis ssp. cremoris on the viscosity of fermented milks. Int. Dairy J. 12:689-695. https://doi.org/10.1016/S0958-6946(01)00161-3.

Sadishkumar, V., and K. Jeevaratnam. 2017. In vitro probiotic evaluation of potential antioxidant lactic acid bacteria isolated from idli batter fermented with Piper betle leaves. Int. J. Food Sci. Technol. 52:329-340. https://doi.org/10.1111/ijfs.13284.

Sakaridis, I., N. Soultos, C. I. Dovas, E. Papavergou, I. Ambrosiadis, and P. Koidis. 2012. Lactic acid bacteria from chicken carcasses with inhibitory activity against Salmonella spp. and Listeria monocytogenes. Anaerobe 18:62-66. https://doi.org/10.1016/j .anaerobe.2011.09.009.

Santini, C., L. Baffoni, F. Gaggia, M. Granata, R. Gasbarri, D. di Gioia, and B. Biavati. 2010. Characterization of probiotic strains: An application as feed additives in poultry against Campylobacter jejuni. Int. J. Food Microbiol. 141:S98-S108. https://doi.org/10 .1016/j.ijfoodmicro.2010.03.039

Setyawardani, T., W. P. Rahayu, R. R. Maheswari, and N. S. Palupi. 2014. Antimicrobial activity and adhesion ability of indigenous lactic acid bacteria isolated from goat milk. Int. Food Res. J. 21:959-964.

Sharifi Yazdi, M. K., A. Davoodabadi, H. R. Khesht Zarin, M. Tajabadi Ebrahimi, and M. M. Soltan Dallal. 2017. Characterisation and probiotic potential of lactic acid bacteria isolated from Iranian traditional yogurts. Ital. J. Anim. Sci. 16:185-188. https://doi.org/10 $.1080 / 1828051 X .2016 .1222888$.

Sharma, P., S. K. Tomar, P. Goswami, V. Sangwan, and R. Singh. 2014. Antibiotic resistance among commercially available probiotics. Food Res. Int. 57:176-195. https://doi.org/10.1016/j.foodres .2014 .01 .025 .

Sharpe, M. E. 1979. Identification of the lactic acid bacteria. Page 233-259 in Identification Methods for Microbiologists. F. A. Skinner and D. W. Lovelock, ed. Academic Press, London, UK.

Shehata, M. G., S. A. El Sohaimy, M. A. El-Sahn, and M. M. Youssef. 2016. Screening of isolated potential probiotic lactic acid bacteria for cholesterol lowering property and bile salt hydrolase activity. Ann. Agric. Sci. 61:65-75. https://doi.org/10.1016/j.aoas.2016.03 .001 .
Silanikove, N., G. Leitner, and U. Merin. 2015. The interrelationships between lactose intolerance and the modern dairy industry: Global perspectives in evolutional and historical backgrounds. Nutrients 7:7312-7331. https://doi.org/10.3390/nu7095340.

Suskovic, J., B. Brkic, S. Matosic, and V. Maric. 1997. Lactobacillus acidophilus M92 as potential probiotic strain. Milchwissenschaft 52:430-435.

Tang, H., B. Qian, B. Xia, Y. Zhuan, Y. Yao, R. Gan, and J. Zhang. 2018. Screening of lactic acid bacteria isolated from fermented Cor nus officinalis fruits for probiotic potential. J. Food Saf. 38:e12565. https://doi.org/10.1111/jfs.12565.

Todorov, S. D. 2008. Bacteriocin production by Lactobacillus plantarum MA isolated from Amasi, a Zimbabwean fermented milk product and study of adsorption of bacteriocin AMA-K to Listeria sp. Braz. J. Microbiol. 39:178-187. https://doi.org/10.1590/S1517 -83822008000100035 .

TMC (Transparency Market Research). 2013. Probiotics Market (Dietary Supplements, Animal Feed, Foods \& Beverages) - Global Industry Analysis, Market Size, Share, Trends, Analysis, Growth and Forecast, 2012 - 2018. Accessed Jul. 31, 2018. http://www .transparencymarketresearch.com/probiotics-market.html.

TMC (Transparency Market Research). 2017. Digestive Health Products Market (Product Type - Dairy Products, Bakery Products and Cereals, Non-alcoholic Beverages; Ingredient - Probiotics, Prebiotics, Food Enzymes; Sales Channel - Modern Trade, Convenience Stores, Online Retailers) - Global Industry Analysis, Size, Share, Growth, Trends and Forecast 2017-2022. Accessed Jul. 31, 2018. https://www.transparencymarketresearch.com/digestive -health-products-market.html.

Tsai, C. C., H. Y. Hsih, H. H. Chiu, Y. Y. Lai, J. H. Liu, B. Yu, and H. Y. Tsen. 2005. Antagonistic activity against Salmonella infection in vitro and in vivo for two Lactobacillus strains from swine and poultry. Int. J. Food Microbiol. 102:185-194. https://doi.org/ 10.1016/j.ijfoodmicro.2004.12.014.

Tsai, C. C., L. F. Huang, C. C. Lin, and H. Y. Tsen. 2004. Antagonistic activity against Helicobacter pylori infection in vitro by a strain of Enterococcus faecium TM39. Int. J. Food Microbiol. 96:1-12. https://doi.org/10.1016/j.ijfoodmicro.2003.10.019.

Vinderola, G., B. Capellini, F. Villarreal, V. Suarez, A. Quiberoni, and J. Reinheimer. 2008. Usefulness of a set of simple in vitro tests for the screening and identification of probiotic candidate strains for dairy use. Lebensm. Wiss. Technol. 41:1678-1688. https://doi.org/ 10.1016/j.lwt.2007.10.008

Wisselink, H. W., R. A. Weusthuis, G. Eggink, J. Hugenholtz, and G. J. Grobben. 2002. Mannitol production by lactic acid bacteria: A review. Int. Dairy J. 12:151-161. https://doi.org/10.1016/S0958 $-6946(01) 00153-4$.

$\mathrm{Xu}, \mathrm{H}$., H. S. Jeong, H. Y. Lee, and J. Ahn. 2009. Assessment of cell surface properties and adhesion potential of selected probiotic strains. Lett. Appl. Microbiol. 49:434-442. https://doi.org/10 .1111/j.1472-765X.2009.02684.x.

Zhang, X., Y. Wang, L. Liu, Y. Wei, N. Shang, X. Zhang, and P. Li. 2016. Two-peptide bacteriocin PlnEF causes cell membrane damage to Lactobacillus plantarum. Biochim. Biophys. Acta 1858:274280. https://doi.org/10.1016/j.bbamem.2015.11.018.

\section{ORCIDS}

R. C. Reuben (1) https://orcid.org/0000-0001-8084-2387

P. C. Roy ๑ https://orcid.org/0000-0003-2369-3551

S. L. Sarkar (1) https://orcid.org/0000-0002-1937-8949

I. K. Jahid ๑ https://orcid.org/0000-0003-0717-0806 